Review

\title{
Aeroterrestrial and Extremophilic Microalgae as Promising Sources for Lipids and Lipid Nanoparticles in Dermal Cosmetics
}

\author{
Maya Stoyneva-Gärtner ${ }^{1}\left[\mathbb{D}\right.$, Blagoy Uzunov ${ }^{1, *}(\mathbb{D})$ and Georg Gärtner ${ }^{2}$ \\ 1 Department of Botany, Faculty of Biology, Sofia University "St. Kliment Ohridski”, 8 Blvd. Dragan Tsankov, \\ 1164 Sofia, Bulgaria; mstoyneva@uni-sofia.bg \\ 2 Institut für Botanik, Universität Innsbruck, Sternwartestrasse 15, 6020 Innsbruck, Austria; \\ georg.gaertner@uibk.ac.at \\ * Correspondence: buzunov@uni-sofia.bg
}

check for

updates

Citation: Stoyneva-Gärtner, M.;

Uzunov, B.; Gärtner, G.

Aeroterrestrial and Extremophilic Microalgae as Promising Sources for Lipids and Lipid Nanoparticles in Dermal Cosmetics. Cosmetics 2022, 9,

11. https://doi.org/10.3390/

cosmetics 9010011

Academic Editors: Eliana B. Souto, Patricia Severino, Anđelka Kovačević and Enzo Berardesca

Received: 1 December 2021

Accepted: 11 January 2022

Published: 17 January 2022

Publisher's Note: MDPI stays neutral with regard to jurisdictional claims in published maps and institutional affiliations.

Copyright: (C) 2022 by the authors. Licensee MDPI, Basel, Switzerland. This article is an open access article distributed under the terms and conditions of the Creative Commons Attribution (CC BY) license (https:// creativecommons.org/licenses/by/ $4.0 /)$.

\begin{abstract}
Microscopic prokaryotic and eukaryotic algae (microalgae), which can be effectively grown in mass cultures, are gaining increasing interest in cosmetics. Up to now, the main attention was on aquatic algae, while species from aeroterrestrial and extreme environments remained underestimated. In these habitats, algae accumulate high amounts of some chemical substances or develop specific compounds, which cause them to thrive in inimical conditions. Among such biologically active molecules is a large family of lipids, which are significant constituents in living organisms and valuable ingredients in cosmetic formulations. Therefore, natural sources of lipids are increasingly in demand in the modern cosmetic industry and its innovative technologies. Among novelties in skin care products is the use of lipid nanoparticles as carriers of dermatologically active ingredients, which enhance their penetration and release in the skin strata. This review is an attempt to comprehensively cover the available literature on the high-value lipids from microalgae, which inhabit aeroterrestrial and extreme habitats (AEM). Data on different compounds of 87 species, subspecies and varieties from 53 genera (represented by more than 141 strains) from five phyla are provided and, despite some gaps in the current knowledge, demonstrate the promising potential of AEM as sources of valuable lipids for novel skin care products.
\end{abstract}

Keywords: carotenoids; Cyanoprokaryota; fatty acids; morphological type; PUFA; Ochrophyta; Rhodophyta; Chlorophyta; Streptophyta; sterols

\section{Introduction}

The increasing use of microalgae in the cosmetic industry as extraordinary rich source of novel high-value functional products, obtained in eco-friendly and cost-effective processes, is widely recognized [1,2]. To date, more than 15,000 novel compounds of algal origin have been identified [3]. Many bio-based microalgal products are often "multipurposed" and are applied in dermal cosmetics as sunscreens, skin sensitizers and colorants, as well as agents for moisturizing, water-binding, texturizing, thickening, tanning, whitening, etc. [2,4-8]. In such skin-related applications, the chemically and functionally diverse group of lipids and their derivates comprise a significant gradient $[9,10]$. Apart from the fact that deficiencies in cutaneous lipids cause discomfort, which may lead to serious skin diseases (e.g., atopic dermatitis, psoriasis, acne, rosacea, hereditary ichthyoses, allergic and irritant contact dermatitis and hidradenitis suppurativa), the broad usage of lipids is based also on their ability to form a protective multifunction skin barrier and on their role as emollients or emulsifiers in the bulk of care and make-up products as well $[9,11]$. Today, with the flourishing development of nanotechnology, which leads to a fast product innovation [12,13], the potential of lipid nanoparticles (LNP), which seem to be both effective and economic, has been recognized as promising [14]. For example, in dermal cosmetics, about a decade ago, 
it was already demonstrated that nano-sized sunscreen products have better performance than micron-sized materials [15].

Therefore, currently, nano-sized systems are being increasingly studied and applied to encapsulate active ingredients in order to enhance the efficacy of their percutaneous delivery to targeted cells and are also used to improve the physiochemical stability of skinbased cosmetic products [16]. Such loaded LNP have the advantage of a cumulative effect achieved by a combination of their easier penetration with the enhanced and prolonged release of the carried ingredient to the targeted cellular and subcellular regions [17-19]. In this way, the overall functionality of the final product is improved, allowing LNP-based cosmetic formulations to be highly effective in skin protection, in treating dermatological disorders and in antiaging therapy [17-19]. In addition, many loaded LNP may provide glowing skin [19]. All these positive effects can be achieved not only by topical skin administrations but also by oral applications [19], and it is easily explainable that the modern dermal cosmetic industry is searching for new high-value functional lipid products of natural origins.

Moreover, in the recent conditions of our society, with growing consumer demands for vegetal oils, there is a rapidly increasing general interest in lipid-rich microalgae $(>20 \%$ of lipids on a cell dry weight basis), named oleaginous [10,20]. Evidence has been accumulated that the average lipid content in microalgae varies between 1 and $70 \%$, but in certain conditions, it can reach $90 \%$ of dry weight (for details, see Reference [21]). This commercial interest is strongly supported by the fact that many oleaginous microalgae can be cultivated at a production scale both autotrophically and heterotrophically, mostly with inexpensive nutrient regimes, and have faster growth rates with high biomass productivity as compared to terrestrial crops [2,22-24]. Further comparisons show that microalgae have even more advantages, since they can be grown all-year-round without the use of arable land, have low water consumption and have low environmental impact [25]. Another important fact that has to be taken into account is the great general biodiversity of microalgae, which is far away from being thoroughly studied and is gaining increasing attention due to recent surge in searching for indigenous commercially important strains or phycoprospecting $[2,26,27]$.

Lipids produced by microalgae belong to two major groups of polar lipids and nonpolar, or neutral lipids $[25,28,29]$. Polar lipids have an important role in cell structure and cell signaling processes and are commonly known also as structural or membrane lipids [28,29]. They comprise a small part of the total lipid fraction in cells (ca. $20 \%$ ) and usually have long chains of extractable fatty acids (FtAs) [25,28-30]. Nonpolar lipids have diverse biological functions, but most of them, triglycerides in particular, are often pointed out as responsible for energy storage [28]. Most oleaginous microalgae have the capacity to produce significant amounts of nonpolar lipids (up to $80 \%$ of the total cell lipid content), the accumulation of which can be influenced, especially in conditions of a lack of nutrients or in stress environments [25,28].

The capacity of microalgae to produce lipids in such appreciable amounts, combined with the advantages of their growing, has stimulated considerable interest in their screening for useful and unusual lipid compositions and their mass cultivation as a feedstock for various biotechnological products [29]. Until now, most research has been oriented towards freshwater, marine and hyperhaline aquatic species from the genera Aphanizomenon, Arthrospira, Chlorella, Desmodesmus, Dunaliella, Haematococcus, Nannochloropsis, Scenedesmus and Spirulina [2]. However, the commercial potential of microalgae inhabiting many other aeroterrestrial or extreme habitats remains untapped [2]. The species from these inimical environments had to develop ultrastructural, physiological and biochemical adaptive features, which include a series of protective natural compounds of special interest for future applications in human life and cosmetics in particular [2]. Moreover, such microalgae can be successfully cultivated in outdoor conditions detrimental for standard crops and other algae [31].

The aim of the present review is to summarize the current knowledge on the aeroterrestrial and extremophilic microalgae (AEM) with a promising potential for obtaining 
lipids and LNP with dermal cosmetic applications. In addition, considering that: (1) experiments have demonstrated the successful increase of the oral bioavailability of lipophilic carotenoids obtained through their combination with other lipid-based formulations (e.g., palm oil and polysorbate) [32] and (2) the nanoparticle-based cosmetic products recently available on the market (for details, see Reference [19]) do not contain microalgal lipids, this review summarizes the data on diverse bioactive lipid compounds recorded in AEM. We believe that this review will encourage the further investigation of microalgae from these underestimated ecological groups and their commercial use in modern cosmetics.

\section{Materials and Methods}

The present review is based on the relevant sources from known databases, including Google Scholar, Science Direct, MEDLINE (PubMed), Web of Science, Scopus and SciFinder and our private scientific libraries and archives as well. In this way, the found publications on the topic covered a period of the last 56 years starting from 1965. The keywords used for search included all lipid classes and subclasses, skin diseases, cosmetic products and ways of application, and names of taxonomic and ecological groups of algae, as well as the names of certain species and genera. Due to the limited volume of the paper, when possible, references to more general reviews were preferred.

In lack of an internationally agreed-upon definition, lipids are loosely considered as biological substances that are generally hydrophobic in nature and, in many cases, soluble in organic solvents $[10,33]$. Different approaches have been applied to classify lipids, but in the present review, we follow the eight categories in the extended LIPID MAPS comprehensive classification with their relevant abbreviations: fatty acyls (FA), glycerolipids (GL), glycerophospholipids (GP), sphingolipids (SP), sterol lipids (ST), prenol lipids (PR), saccharolipids (SL) and polyketides (PK) [34].

Beyond the scope of this review are the methods for the preparation and characterization of LNP for skin care applications and the mechanisms of their penetration, which have been described in detail [14,19]. Although we use the general term "lipid nanoparticles" with the abbreviation LNP, whenever possible, according to the data availability, we indicate the exact class of lipid-based nanoparticulate systems utilized in cosmetic products recognized by Reference [19]: solid LNP, nanostructured lipid carriers, liposomes and nanoemulsions.

In the review, the terms "cosmetics/cosmetic industry" are used in their broadest sense, embracing the recently proposed but still debatable terms "cosmeceutics/cosmeceutical", which consolidate between cosmetics and pharmaceuticals, based on the medicinal utility of biologically active compounds (for details, see References [2,5]), and "cosmotherapy", which considers therapeutically efficacious cosmetics (for details, see Reference [19]).

Since the term "algae" has no taxonomic standing, its scope and understanding of AEM in particular, as well as of their ecological groups, are in accordance with the definitions provided in References [2,35]. In this approach, algae from soils, rock, bark and leaf surfaces and building facades are named aeroterrestrial, while algae from caves, ice, snow, permafrost, cryoconites and thermal springs, as well as from unusual acidic habitats, are considered extremophilic. The algal nomenclature follows Algaebase [36], with the synonyms shown at the first appearance of the relevant Latin name.

\section{Results}

Data on the lipids, detected in more than 141 strains of 87 species, subspecies and varieties from 53 genera of AEM, are presented below in the text, following the order of the major lipid categories in the extended LIPID MAPS comprehensive classification [34].

\subsection{Fatty Acyls (FA) from AEM}

FA are a diverse group of molecules, included in one of the most fundamental categories of biological lipids, because the fatty acyl structure represents the major lipid building block of complex lipids (i.e., lipids that yield three or more products on hydrol- 
ysis) [33]. It is characterized by a repeating series of methylene groups, responsible for the hydrophobic characteristic of this category [33]. FA are subdivided into classes, which include FtAs, fatty acid esters (FAEs), fatty alcohols, fatty amides, monoradylglycerols, diradylglycerols, triaradylglycerols, etc. [33].

\subsubsection{Fatty Acids (FtAs) from AEM}

In microalgae, a variety of $135 \mathrm{FtAs}$ has been recorded [37]. FtAs comprise the major component of lipids, which can account from $20 \%$ to $50 \%$ of the dry biomass, but also, other values $(1-70 \%)$ have been reported $[22,38]$. This peculiarity makes microalgae essentially beneficial for industrial cosmetics, in which FtAs have broad applications as raw materials in soaps, as emollients, emulsifiers, softeners, etc. [39].

There are different ways to classify FtAs, but quite commonly in microalgal studies, they are discussed in three categories based on their saturation, such as polyunsaturated fatty acids (PUFA), saturated acids (SAFA) and monounsaturated fatty acids (MUFA). PUFA are largely spread in structural polar lipids, but SAFA and MUFA comprise the storage lipid fraction [25,28-30]. Another often-used term is "essential fatty acids" (EFA), which refers to necessary for health PUFA that cannot be synthesized in the body and must be obtained from foods [40]. EFAs embrace mostly PUFA from the families of the so-called

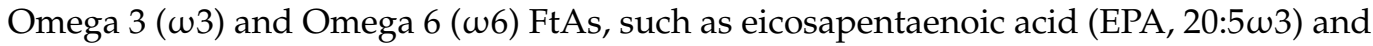
docosahexaenoic acid (DHA, 22:6w3), with their intermediate, docosapentaenoic acid (DPA, 22:5w3) [28].

PUFA, and the essential $\omega 6$ linoleic acid (18:2w6), in particular, as a natural part of the skin epidermis, are important for proper skin functioning, and their application shows beneficial effects on the skin [39-43]. For example, a deficiency of linoleic acid results in a scaly skin disorder and excessive epidermal water loss $[39,42,44,45]$, but its application is useful in the treatment of hyperplasia of the skin [2,7]. The use of PUFA ( $\omega 3, \omega 6$ and $\omega 9$ PUFA in particular) for skin protection is gaining increased attention, because they have been proven helpful for maintaining membrane fluidity, improving skin barrier function and skin homeostasis, reducing of trans-epidermal skin loss, the acceleration of skin wound healing, ensuring photoprotection, the prevention of skin cancer development and the alleviation of skin impairments (e.g., acne), photoaging, allergy, dermatitis, cutaneous wounds and melanogenesis (thus treating hyperpigmentation) [2,10,41,43,46-60]. The application of PUFA as surfactants in soaps and other skin care products is well-known. To exemplify once more the great potential of PUFA in dermal human cosmetics, we note here the prepared solid emulsion gel for cell-targeted PUFA delivery to skin wounds [61] and the linoleic acid-loaded liposomes as NP carriers for skin whitening [62]. The effect was greater for liposomal $(0.1 \%)$ than for free linoleic acid, and liposomal encapsulation protected the unstable linoleic from oxidation [62]. Higher effects of a final cosmetic product, obtained by application of the nanoemulsion matrix enriched on long-chain PUFA, were also reported [12].

In addition to all the beneficial effects enlisted above, PUFA are supposed to have a cryo-protective role, which helps to prevent intracellular ice crystal formation [63]. Considering this, here, we outline the high PUFA levels (58.1-65.8\% of the total lipids, mainly the $\omega 3$ essential $\alpha$-linolenic acid, 18:3 $\omega 3$ ) in the extremophilic unicellular green Chloromonas hindakii, which causes "orange snow" [64]. This species, like other cryophilic algae from Chlamydomonadaceae, produces two types of cells during its life cycle: green-colored flagellated (monadal) cells, which dwell in melting snow, and nonmotile resting thick-walled cells of orange-reddish color, which thrive on the snow surface. The SAFA (mainly palmitic acid, 16:0) and MUFAs (mainly oleic acid, 18:1 $\omega 9$ ) comprised 23\% and 9.4\%, respectively, of the total lipid content [64]. These relatively high levels of palmitic and oleic acid in C. hindakii correspond to their similar amounts in other strains of Chloromonas $[64,65]$. In C.

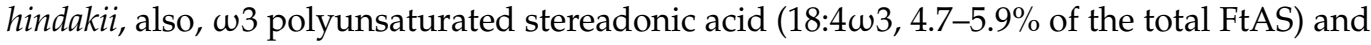

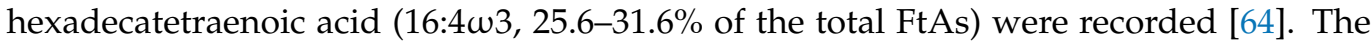
same production of hexadecatetraenoic acid was detected earlier in another snow alga, 
Chloromonas remiasii CCCryo 005-99, kept under nitrogen-deficient conditions [63]. This acid is of interest for modern dermal cosmetics, because it can mitigate several inflammatory and allergic reactions [49].

A high content (45-50\% of all FtAs) of PUFA with lower amounts of SAFA (30-40\%) and MUFA (10-15\%) was detected also in the "red snow" samples containing mainly the cryophilic green unicellular algae Chloromonas alpina, Chloromonas nivalis (incl. subsp. tatrae), Chloromonas polyptera and Chloromonas spp.; some uncultured species of the family Chlamydomonadaceae and in the filamentous Raphidonema sempervirens [66,67]. High levels of PUFA are also common for two cryophilic strains of green algae isolated from lake ice, the filamentous Ulothrix zonata [68] and unicellular Monoraphidium sp. [31]. The last strain was recognized as a prospective candidate for low-temperature biotechnology because of its successful outdoor cultivation under early winter conditions with average temperatures of $10.0{ }^{\circ} \mathrm{C}$ [31]. In these conditions, it had a lipid productivity of $162 \mathrm{mg} \mathrm{L}^{-1} \mathrm{day}^{-1}$, with a production of 16:4 and 18:4 FtAs reaching 27.5 and $43.7 \mathrm{mg} \mathrm{L}^{-1} \mathrm{day}^{-1}$, respectively, which is one order of magnitude higher than the previously reported values. The proportion of these acids of total FtAs was up to $19.1 \%$ and/or 34.7\%, respectively [31].

A high FtAs content was detected in the aeroterrestrial unicellular green Coelastrella striolata var. multistriata isolated from the rock surface [69]. During cultivation, this alga changed the cell color from green to reddish, depending on the nitrogen concentration in the culture media [69]. Both green and red cells contained SAFA (mostly palmitic acid) and PUFA, but differences in the amount of specific PUFA were registered. For example, in the green cells, linoleic acid predominated, reaching $22.7 \mathrm{mg}$ per $\mathrm{g}$ dry weight cells $\left(\mathrm{mg} \mathrm{g}^{-1} \mathrm{dwc}\right)$ from the total lipid content of $90 \mathrm{mg} \mathrm{g}^{-1} \mathrm{dwc}$. In the orange-reddish cells, oleic acid was the most abundant, reaching $113.4 \mathrm{mg} \mathrm{g}^{-1} \mathrm{dwc}$ from the total lipid content of $319 \mathrm{mg} \mathrm{g}^{-1} \mathrm{dwc}$ [69].

In the aeroterrestrial coenobial green Tetradesmus obliquus (Syn. Scenedesmus obliquus), the total lipids comprised $10.3 \% \mathrm{~g} 100 \mathrm{~g}^{-1}$, PUFA were $47.31 \%$ from all unsaturated FtAs, representing predominantly $\omega 3$ linolenic acid (16.74\%), and by ca. $9.70 \%$ of $\omega 6$ FtAs, such as linoleic and linolelaidic acids (18:2 w6) [70]. These results correspond to earlier data on FtAs profiles of this alga [71-73] with high amounts of linolenic acid ( $>15 \%)$, oleic acid $(>14 \%)$ and linoleic acid (>10\%) [72] and suggest its use as their potential source [70].

The analysis of three aeroterrestrial filamentous cyanoprokaryotes, namely Anabaena cylindrica, "Nostoc canina" (we suppose that this is an isolated photobiont of the lichen Peltigera canina) and Desmonostoc muscorum (Syn. Nostoc muscorum), revealed that their total lipid content varied between 10.7 and $12.3 \%$ of the dry weight with a high content $(>50 \%)$ of PUFA [74]. Some species-specific differences in FtAs compositions were detected: palmitic acid, linoleic acid and linolenic acid were predominant in Anabaena cylindrica; palmitic, palmitoleic, oleic and linoleic acids were the most abundant in Nostoc canina and palmitic, palmitoleic, hexadecadienoic, oleic and linoleic acids dominated in D. muscorum [74]. The authors outlined the differences with another species of Nostoc, namely N. calcicola (strain 1453-1), in which linolenic acid was dominant [75].

The lipid analyses of ten oleaginous soil algal isolates, comprised by three filamentous cyanoprokaryotes (Tolypothrix sp. PBGA1, Tolypothrix sp. PBGA2 and Oscillatoria sp. PBGA3) and seven unicellular green algae (Acutodesmus dissociatus TGA1, Chlorella sp. TGA2, Chlorella sp. TGA4, Chlorella sp. PGA2, Hindakia tetrachotoma PGA1 and two unidentified species from the order Chlamydomonadales ("Chlamydomonadales species" TGA3 and "Chlamydomonadales species" TGA5), indicated that green algae accumulate more lipids than cyanoprokaryotes [76]. The study proved the high lipid productivity of Acutodesmus dissociatus TGA1 (22 mg L $\left.\mathrm{m}^{-1} \mathrm{~d}^{-1}\right)$ caused by its greater biomass productivity $\left(119 \mathrm{mg} \mathrm{L}^{-1} \mathrm{~d}^{-1}\right)$ and fast specific growth rate ( $\mu \exp -0.23$ day $\left.^{-1}\right)$. Similarly, high lipid content, high lipid productivity and beneficial biomass yield were shown by Chlorella sp. TGA2 (28\%, $27 \mathrm{mg} \mathrm{L}^{-1} \mathrm{~d}^{-1}$ and $115 \mathrm{mg} \mathrm{L}^{-1} \mathrm{~d}^{-1}$, respectively) and by Hindakia tetrachotoma PGA1 25.70\%, $20 \mathrm{mg} \mathrm{L}^{-1} \mathrm{~d}^{-1}$ and $89 \mathrm{mg} \mathrm{L}^{-1} \mathrm{~d}^{-1}$, respectively) [76]. In Acutodesmus dissociatus TGA1, Chlorella sp. TGA2 and Hindakia terachotoma, the most abundant was palmitic acid, followed by oleic acid [76]. These data were in agreement with the formerly published 
predominance of palmitic acid in most algae with common values between 20 and $27 \%$ but with a possibility to reach 49-50\% [77]. In addition, the strain "Chlamydomonadales species" TGA3 was outlined as a promising feedstock for biotechnology as "considerably thermotolerant" [76].

An interesting strain (K-1) of the unicellular green species Parietochloris alveolaris (Syn. Lobosphaera incisa), described from alpine soils and reported as occurring as a photobiont in lichens, was recently isolated from a tidal flat [78]. K-1 has higher proportions of $\omega 3 \mathrm{FtAs}$ (including $\alpha$-linolenic acid and EPA) than other strains of the same species investigated earlier [79] and was outlined as a strongly promising source of $\omega$ PUFA [78]. Before this study, P. alveolaris was already declared to be the richest natural source of the peculiar, high-value polyunsaturated $\omega 6$ arachidonic acid (AA, 20:4w6) [80], with high contents in its all studied strains [81]. Its specific delta5 desaturase mutant was proven as a novel source for the large-scale production of the valuable long-chain polyunsaturated dihomo- $\gamma$ linolenic acid (20:3n6), a precursor of the AA [82]. Dihomo- $\gamma$-linolenic acid is of particular interest for dermal applications due to its successful implementation in the treatment of inflammatory disorders, such as atopic eczema and psoriasis $[82,83]$.

Another alga, rich in the relatively rare AA, is the unicellular red Porphyridium purpureum (Syn. P. cruentum) [84], which develops in various habitats, including soil surfaces [36]. Besides AA, this aeroterrestrial alga also contains beneficial amounts of EPA [84]. A high content of both valuable long-chain PUFAs was detected on the background of a total lipid content ranging between 9 and 19\% dry weight biomass and a lipid productivity up to $34 \mathrm{mg} \mathrm{L}^{-1}$ day $[21,25,85-89]$. Since the total AA and EPA recoveries reached $39.5 \%$ and $50.8 \%$, respectively, for a purity $\sim 97 \%$ for both FtAs, P. purpureum was considered promising for lipid-based industrial applications $[21,25,84,89]$. High proportions of EPA were also detected in another soil inhabitant, the unicellular eustigmatophycean alga Monodopsis subterraneus (Syn. Monodus subterranea) from division Ochrophyta [90]. Since EPA accounted up to $36.7 \%$ of all FtAs and up to $4.4 \%$ of dry weight, $M$. subterraneus was declared as one of the most promising candidates for its phototrophic production [91,92]. Later, through the manipulation of culture conditions and strain selection, EPA productivity reached $56 \mathrm{mg} \mathrm{L}^{-1} 24 \mathrm{~h}^{-1}$ [93], and a yield of $96.3 \mathrm{mg} \mathrm{L}^{-1}$ was obtained from its strain UTEX 151 [94].

PUFA profiles of the polyextremophilic unicellular red alga, isolated from acidic thermal spring and identified as Galdieria sp. USBA-GBX-832, provided the first evidence for the synthesis of AA and EPA in this genus [95]. However, both FtAs were detected only in trace concentrations $(<0.25 \%)$ [95]. The amount of total lipids ranged between 4.0 and $5.0 \mathrm{mg}$ and was higher under autotrophic culture conditions ( $15.3 \%$ of dry biomass) than under heterotrophic and mixotrophic conditions (ca. 3.7\% of dry biomass) [95]. In the same study, SAFA (mostly palmitic acid, 27.9\%) and stearic acid (C18:0), 24.3\%) comprised $25 \%$ of all FtAs produced under autotrophic conditions. By contrast, SAFA, obtained under hetero- and mixotrophic conditions and, especially, palmitic acid ( $27 \%)$, accounted for $40-47 \%$ of FtAs. In autotrophic conditions, no MUFA were detected, while, under hetero- and mixotrophic conditions, the most abundant MUFA was oleic acid (28.2\% and $34.1 \%$, respectively). PUFA (predominantly linoleic acid) comprised $17 \%$ under autotrophic conditions and accounted for ca. $21 \%$ in both other cases [95]. These results on PUFA correspond to earlier reports on 45 other strains of G. sulphuraria $[65,96]$. These two studies revealed low amounts of lipids (in comparison with $26-32 \%$ proteins and $63-69 \%$ polysaccharides) but demonstrated the presence of valuable palmitic, oleic, linoleic and linolenic acids, with small amounts (traces) of myristic, palmitoleic and stearic acids $[65,96]$. The comparison of these polyextremophilic strains of G. sulfuraria, isolated from acid thermal springs ( $\mathrm{pH}=0-4$, water temperature up to $56{ }^{\circ} \mathrm{C}$ ) with its acidic but non-thermophilic strain (growth optimum of 30-35 ${ }^{\circ} \mathrm{C}$ ), showed no obvious differences in FtAs [97].

In another acidophilic alga, the unicellular green Dunaliella acidophila, which grows at $\mathrm{pH} 0.2-2.5$, the nonpolar lipids consisted predominantly of FtAs $(14 \%$ of ethyl ether extract), namely linolenic, $\gamma$-linolenic, linoleic, oleic and elaidic acids [98]. In the same 
study, three hydroxy fatty acids, which have never been detected in other algae, were identified as methyl esters: methyl (12R)-hydroxyoctadeca-9Z,13E,15Z-trienoate, methyl (9S)-hydroxyoctadeca-10E and 12Z,15Z-trienoate and methyl ricinoleate.

\subsubsection{Fatty Acid Esters (FAEs) from AEM}

FAEs are represented by wax monoesters, wax diesters, lactones, etc. [33]. In cosmetics, waxes are used as texturizer agents to regulate the viscosity of formulations and increase their protective and lubricant properties $[9,10,17,99,100]$. Therefore, waxes are important and dermatologically well-tolerated ingredients that improve the rigidity, hardness, texture and stability of lipsticks [10]. However, today, waxes from AEM are very poorly known. They have been found among the main constituents of lipids in the unicellular green Chlorella vulgaris, together with glycolipids, hydrocarbons, phospholipids and small amounts of free FtAs [24,101,102]. This aeroterrestrial alga can produce $11-40 \mathrm{mg} \mathrm{L}^{-1}$ day $^{-1}$ lipids, which account from 5 to $58 \%$ of the dry biomass [21].

Lactones are natural secondary metabolites, constituted from cyclic carboxylic esters, which have received considerable attention from the scientific community due to the broad range of their biological activities [103-105]. Regarding dermal cosmetics, their general antimicrobial, antibacterial, antifungal, insect-repellent, anti-inflammatory and antitumor properties are important $[103,104]$. For example, the furanocoumarins, a subclass of lactones, are extremely important in the treating of skin disorders, such as vitiligo, psoriasis, dermatitis, eczema, leukoderma and different mycoses, because they can promote the pigmentation of affected areas [103].

Lactones have been isolated from a wide range of living organisms, mostly plants, fungi and marine sponges [103,105]. Concerning algae, the studies have been based mainly on marine and few freshwater species [105-114]. In marine algae, apart from common oxygenated FtAs derivatives, a number of complex and unique compounds were found (e.g., cyclopropyl hydroxyeicosanoids, egregiachlorides, ecklonialactones, hybridalactones, bicyclic cymathere ethers, cymatherelactones and cymatherols-for details, see Reference [108]. New lactones were also discovered in freshwater species (e.g., sesquiterpenes $3 \alpha, 4 \alpha, 8 \alpha$-trihydroxy-10 $\alpha$-methoxy- $1 \alpha, 5 \alpha, 7 \alpha, 11 \beta H$-guaia, $6 \alpha, 12$-olide and $4 \alpha, 8 \alpha$-dihydroxy-10 $\alpha$-methoxy- $1 \alpha, 5 \alpha, 7 \alpha, 11-\beta H$-guaia, $6 \alpha, 12$-olide [106]), and for the first time, coriolic acid, a precursor of $\delta$-decalactone, was reported in cyanoprokaryotes [114].

In contrast with aquatic algae, lactones from AEM are yet poorly known. Studies have mainly addressed the oxygenated derivatives of PUFA, collectively termed oxylipins, which showed antibacterial, anti-inflammatory and antiallergic activity and alleviated the effects from diverse kinds of stress, desiccation, wounds and pathogen infections [108,112,114]. The endogenous lipoxygenase (LOX)-derived oxylipins were determined in aeroterrestrial filamentous Nostoc punctiforme PCC73102 and Nostoc sp. PCC7120 [115,116] and in the green unicellular Edaphochlamys debaryana (Syn. Chlamydomonas debaryana) [112]. In another green, but extremophilic, alga, Dunaliella acidophila, three new methyl esters ere identified as new for algae: methyl (12R)-hydroxyoctadeca-9Z,13E,15Z-trienoate, methyl (9S)-hydroxyoctadeca-10E, 12Z,15Z-trienoate and methyl ricinoleate [98]. The findings of these compounds and earlier data, obtained on the antibacterial properties of Chlorella vulgaris [117], allow to suppose the great untapped potential of AEM as lactone sources and to encourage their future research.

\subsubsection{Fatty Alcohols, Hydrocarbons and Triradylglycerols from AEM}

Fatty alcohols and hydrocarbons represent separate classes without subclasses in the FA category, whereas the class of triradylglycerols contains several subclasses, including triacylglycerols [33]. Data collected from the few reports of long-chain alcohols in microalgae allowed to suppose that microalgae are not a major source of these lipids [118].

Hydrocarbons derived from FtAs, such as alkanes and alkenes, commonly occur in plants and insects and play an essential role in preventing water loss from their tissues [119]. The synthesis of hydrocarbons is widespread in cyanoprokaryotes [120], but in general, in 
eukaryotic microalgae (except the aquatic Botryococcus braunii [121]) and, particularly, in $\mathrm{AEM}$, it has received little attention [119]. In the aeroterrestrial unicellular green Chlamydomonas reinhardtii, a C17 alkene, n-heptadecene, was detected, and in Chlorella variabilis NC64A eptadecane, pentadecane, as well as 7- and 8-heptadecene, were found [119]. The same study showed that microalgae have the ability to convert C16 and C18 FtAs into alka(e)nes by a new, light-dependent pathway [119].

Triacylglycerols in Dunaliella acidophila comprised 5.2\% of the ethyl ether extract and were represented by trilinolenin, triolein, trielaidin and tristearin [98]. In another green unicellular extremophilic alga, Pseudochoricystis ellipsoidea MBIC11204, isolated from a hot spring, a high amount of triacylglycerols ( $82 \%$ of the total lipid content and about $21 \%$ of the dry weight) was detected in conditions of nitrogen starvation [122]. In the same study, the major FtAs were $\mathrm{C} 18: 1$ and $\mathrm{C} 16: 0$, and the maximum growth rate was $3.46 \mathrm{~g} \mathrm{~L}^{-1}$ day ${ }^{1}$ or $0.144 \mathrm{~g} \mathrm{~L}^{-1} \mathrm{~h}^{-1}$. Therefore, P. ellipsoidea MBIC11204 was considered as a promising fast-growing oleaginous algal strain from which hydrocarbons and triglycerides can be produced photoautotrophically, reaching up to $30 \%$ of the dried biomass [122].

\subsection{Glycerolipids (GL) from AEM}

Glycerolipids (GL) encompass all glycerol-containing lipids of an amphiphilic nature (assembly of FtAs, glycerol and polar heads) [33,123]. GL include: (1) mono-, diand tri-substituted glycerols, from which the best-known are acylglycerols (FAEs of glycerol] [33], and (2) betaine lipids, which are characterized by a non-phosphorous polar head group connected by an ether bond with a diacylglycerol (DAG) backbone [124]. Three types of betaine lipids have been identified: diacylglyceryl- $N, N, N$-trimethylhomo-Ser (DGTS), diacylglyceryl-hydroxymethyl- $N, N, N$-trimethyl- $\beta$-Ala (DGTA) and diacylglycerylcarboxyhydroxymethylcholine (DGCC) [124-126]. All GL are currently very attractive in dermal cosmetics due to exerting therapeutic anticancer, antiviral and anti-inflammatory activities through interactions with other biological molecules (for details, see Reference [123]).

Monogalactosylglycerol (MGD), digalactosylglycerol (DGD), triagalactosylglycerol (TGD), sulphoquinovosyl diacylglycerol (SQD) and phosphatidylglycerol (PSD) in Anabaena cylindrica 1403-2, Nostoc calcicola 1453-1, Oscillatoria chalybea 1459-2 and Tolypothrix tenuis B 1482-3 were analyzed [75]. In the lipid extracts from these aeroterrestrial filamentous cyanoprokaryotes, MGD had the highest proportion (19.2-28.6 weight \%) and was followed by DGD (6.9-9.3\%), SQD (5.6-7.1\%) and PSD (3.3-8.5\%). Only TGD was not detected in Anabaena and Nostoc but comprised 2 and 5\% in Oscillatoria and Tolypothrix, respectively [75]. A later study of Anabaena cylindrica, "Nostoc canina" and Desmonostoc muscorum demonstrated a similar dominance of MGD, DGD, SQD and PSD and reported the occurrence of a highly polar unknown glycolipid in all of them [74]. Experiments with the soil ochrophyte Monodopsis subterraneus showed a decrease of saturated 16:0-16:0 DGD with a parallel increase of unsaturated 20:5-16:1 DGD under phosphate starvation [127].

The study of GL in the red polyextremophilic Galdieria sulfuraria also demonstrated the presence of MGD, DGD and SQD [128]. The same investigation revealed the presence of betaine lipids DGTA and DGTS, the contents of which decreased with the increase of the $\mathrm{pH}$, while the contents of the other glycolipids (i.e., MGD, DGD and SQD) and of the phospholipids (phosphatidylglycerol-PG, phosphatidylcholine/lecithin-PC, phosphatidyletanolamine/cephalin-PE, phosphatidylinositol-PI, phosphatidylserinePS and phosphatidate) increased. This phenomenon was related to the lack of available phosphorus in the culture media, but in general, the replacement of phospholipids by betaine lipids in G. sulphuraria was recognized as a major change in the adaptation to low $\mathrm{pH}$ and high temperatures [128]. However, in six other red algae, including unicellular polyextremophilic Cyanidium caldarium, which develops in low $\mathrm{pH}$ hot springs, and aeroterrestrial Porphyridium purpureum, betaine lipids were not found [128,129]. Considering the complicated taxonomy of Cyanidium, from which Galdieria was derived [36], we suppose that the lack of betaine lipids in Cyanidium needs further proof. 
Betaine lipids are relatively better investigated in marine and freshwater microalgae $[126,129,130]$, with DGTS and DGTA found in the plastid and thylakoid membranes of green algae [125]. It has been demonstrated that, in organisms like Chlamydomonas reinhardtii, betaine lipids (DGTS) seem to replace phospholipids (and particularly PC), a major phospholipid class in most eukaryotes, and instead produces a substantial amount of DGTS regardless of the P concentration [131]. However, betaine lipids remained poorly known in AEM, although there was empirical evidence that glycine betaine is among the essential compounds that allow halophytes to grow in high saline conditions [132].

\subsection{Glycerophospholipids (GP) from AEM}

Glycerophospholipids (GP) are natural lipids, widely spread in living organisms as key components in cell membranes with distinct differences in the structures between domains Eubacteria and Eukarya and domain Archaea (for details, see References [33,133]). In addition to their structural functions, GP can serve as precursors, or as membrane-derived messengers, but can participate in responses to stress [10,33]. GP contain a phosphate (or phosphonate) group esterified to one of the glycerol hydroxyl groups, but it has to be noted that a large number of trivial names are associated with this category [33].

GP commonly occur in microalgae and are used in cosmetic ingredients as excellent emulsifying agents that can stabilize oil-water emulsions as delivery systems [10,134,135]. The distribution of major GP in comparison with betaine lipids was discussed in the text above according to their distribution in unicellular red and green AEM. Data on PUFA domination (65.1\%) over SAFA (18.4\%) and MUFA $(16.6 \%)$ and the detailed participation of FtAs in phospholipids of cryophilic Chloromonas hindakii have been published, with a note that the content of alpha-linolenic acid was up to twice higher in phospholipids than in neutral lipids and glycolipids [64].

\subsection{Sphingolipids (SP) from AEM}

Sphingolipids (SP) are a group of diverse molecules, which have a sphingoid base backbone (synthesized de novo from serine) and a long-chain fatty acyl-CoA [33]. The common name of this base, "sphingosine", means similar to the Sphinx and is connected with the enigmatic (Sphinx-like) properties of these peculiar lipids (for details, see Reference [136]). SP comprise ceramides (which are also precursors of more complex SP), phosphosphingolipids, glycosphingolipids and some others, including protein adducts [33]. SP have a high potential for industry due to their important structural functions in maintaining the integrity of cell membranes and participation in extracellular signaling [137-139]. In addition, SP have demonstrated antimicrobial and antiviral activity [138,140-148].

Ceramides occur in high concentrations in the stratum corneum of the skin and are essential in maintaining the skin barrier properties, such as inhibiting water loss and protecting the ingress of potentially harmful substances [143]. Decreased levels of ceramides lead to the disruption of these barrier functions, which have been impaired in skin diseases such as psoriasis and atopic dermatitis [11,143,149,150]. The topical administration of ceramides was shown to be effective in preventing trans-epidermal water loss [151]. Glycosylceramide can alleviate atopic dermatitis by oral application via dietary intake [151-154], whereas its topical administration improves UV A-induced wrinkle formation and helps in preventing tumor metastasis in mice [155-157]. In addition, glycosylceramides increase the expression of genes involved in tight junctions and ceramide delivery in normal human epidermal keratinocytes [158].

SP have been known more than 100 years [136] but only currently has the accumulated evidence on beneficial skin applications led to their expanded utilization [151]. Despite this gradually increasing focus with a demand for natural sources of SP, up to now, their structural diversity in algae was poorly studied in comparison with mammals, higher plants and fungi [137]. Data on SP are available for aquatic macro- and microalgae from different taxonomic groups [142,144,145,148,151-171]. However, according to our best knowledge, there are no investigations regarding AEM. Considering that new structures 
and new microalgal sources of SP are regularly discovered $[159,167,169,170]$, and that the importance of SP for dermal cosmetics is increasing, future stronger interest in this class of valuable lipids from AEM can be expected.

\subsection{Sterol Lipids (ST) from AEM}

Sterol lipids (ST) are secondary triterpenoid metabolites, which are essential components of cell membranes [172]. They play a role in controlling the membrane stability, fluidity and permeability and influence the functionality of enzymes, receptors and channels [172-175]. ST have anti-inflammatory, anticarcinogenic, antibacterial and antiviral properties and demonstrate strong antioxidant abilities, which support the hypothesis for their origin as protective molecules in the response to reactive oxygen species [172,173,175-178]. ST are divided mainly according to their biological functions and, as a major lipid category, contain the following classes: cholesterol and derivatives, steroids (mainly with hormonal functions and a role in signaling molecules), secosteroids, bile acids and derivatives; steroid conjugates (including taurine conjugates, glycine conjugates, glucorinides and sulfates) and hopanoids [33].

ST show fascinating diversity, but their types and combinations differ between organismic groups $[172,175]$. ST of microalgae, despite not being comprehensively studied, also show great structural diversity and include some rare and unusual compounds but commonly occur in low amounts $[137,179,180]$. Studies of cyanoprokaryotes have provided debatable results on the presence/absence of ST, depending on the species and analytical tests, but when detected, ST were in low amounts $(<0.03 \%$ of the dwc) [172]. However, genetic sequencing revealed several genes with a close sequence match to the genes related to sterol biosynthesis [172].

By contrast, it was stated that all eukaryotic microalgae contain ST [172,175,177]. C27 D5-unsaturated sterol cholesterol, usually considered animal sterol, is surprisingly common in microalgae [172]. However, in comparison with animals, ST profiles of algae show high compositional diversity and are of great interest for natural product research $[180,181]$. Algae produce cycloartenol and utilize the phytosterol biosynthetic pathway in a similar way to the higher plants [175]. Moreover, according to their ST contents, unicellular algae exhibit greater diversity than multicellular algae and plants, being an evolutionary precursor for the cycloartenol-based pathways in higher plants, and are supposed to be an evolutionary transition point for sterols [175]. The free-occurring microalgal ST are frequently, if not always, accompanied by conjugated forms (e.g., steryl glycosides, acyl steryl glycosides, esters (bearing fatty acid residues) and sulfates) of great diversity [137]. Usually, the compositional changes in ST profiles dependent on external factors are small, but some exceptions have been reported, indicating that, besides the taxonomic characteristics, the culturing conditions also need to be considered when comparing data on different species (for details, see Reference [172]).

An analysis of the available publications showed that, regarding ST, the most extensively examined were marine algae (for details, see References $[137,178,180]$. After the first studies in the 1960s indicating chondrillasterol in Scenedesmus [182], there was an increase in interest in freshwater green microalgae $[183,184]$. Their highly diverse sterolomic profiles were demonstrated, proving that even species from one genus can perform substantial differences (for details, see Reference [180]). Likewise, an investigation of marine microalgae (based on 106 cultures of diatoms) revealed their great ST diversity, represented by 44 types, all common with other algae $[175,185]$. Despite the obtained results on ST diversity in microalgae, there are very few investigations concerning AEM.

Historically, the first study of the aeroterrestrial filamentous cyanoporkaryote Drouetiella lurida (Syn. Phormidium luridim) was conducted in 1968 and led to the discovery of seven unsaturated ST [186]. It was followed by analyses on the other seven filamentous aeroterrestrial cyanoprokaryotes, namely Anabaena cylindrica, Calothrix sp., Desmonostoc muscorum, Microcoleus autumnalis (Syn. Phormidium autumnale), "Nostoc canina", Nostoc carneum and Nostoc commune [74,173,187-189]. In Microcoleus autumnalis, the main ST were cholesterol, $\beta$-sitosterol and stigmasterol, with squalene as a precursor, and high amounts of 
ergosterol were produced in a glucose culture [189]. For N. canina, "considerable amounts" of cholesterol and lanosterol were reported [74], while campesterol, sitosterol and clionasterol were detected in Nostoc commune var. sphaeroides $[177,188,190]$. Two unidentified ST were found, and thirteen unsaturated ST were determined in another filamentous aeroterrestrial cyanoprokaryote Scytonema sp. [191]. Among them, cholest-5-en-3 $\beta$-ol (18.9 \%), $3 \beta$-methoxycholest-5-ene (16.2\%) and 3 $\beta$-acetoxycholest-5-ene (11.2\%) dominated [191]. In the same alga, only one tetraenoic sterol, namely ergosta-5,7,22,24(28)-tetraen-3 $\beta$-ol, was determined [191].

The first detection of this rare ST was in the polyextremophilic red Cyanidium caldarium and Galdieria sulphuraria [192]. These species grew on the soil and rocks of the acid hot springs, but a large part of their populations was cryptoendolithic and showed additional possibilities to adapt to low-light regimes inside the rocks [193]. Studies on Galdieria sulphuraria conducted in different light regimes and culture conditions have identified higher levels of ergosterol, the precursor of vitamin D2, under high-light exposure and when glucose was added to the culture [194].

In Chlorella vulgaris, ergosterol, 7-dehydroporiferasterol, ergosterol peroxide, 7-dehydroporiferasterol peroxide and 7-oxocholesterol with anti-inflammatory and anticancer activities were detected [195]. Later, the examination of the ST composition of four other aeroterrestrial unicellular green algae, namely Chlorella variabilis NC64A (symbiotic), Chlorella sorokiniana, Coccomyxa subellipsoidea and Chlamydomonas reinhardtii, also revealed that, in Chlorella, and Chlamydomonas as well, the major sterol was ergosterol, whereas, in Coccomyxa subellipsoidea, which is able to grow at much lower, near-polar temperatures, three phytosterols occurred instead of ergosterol [175].

In Dunaliella acidophila, the ST were $6.4 \%$ of the ethyl ether extract, comprising $\beta$ sitosterol, isofucosterol, 24-methylenlophenol and (24S)-methyllophenol (isolated for the first time in green algae), and, in addition, two unidentified sterols were detected [98]. Other lipids, identified in this green extremophilic alga, were acylsterols (5.4\%) and phytol $(6.4 \%)$ [98].

Since microalgae have been declared as "the most prominent strains" for ST production [173], it has to be noted that almost all the studies cited above have demonstrated that the external conditions and type of cultivation (auto-, hetero- or mixotrophic) influence the amounts of ST. In spite of the great structural diversity and revealed promising sources, one of the limitations in the development of microalgae-derived phytosterols is their low sterol content [172,177], and the commercial exploitation of sterols from microalgae is yet in its infancy [172].

\subsection{Prenol Lipids (PR) from AEM}

Prenol lipids (PR) are synthesized from five-carbon isoprene units and comprise extremely important natural compounds, such as carotenoids, vitamins $\mathrm{E}$ and $\mathrm{K}$, diverse terpenes, etc. [33].

Carotenoids are natural pigments from which currently more than 850 types have been identified [10,196,197]. Carotenoids are "multipurpose" strong antioxidants and scavenging agents, applied in dermal cosmetical formulations such as antiaging, antiinflammatory, tanning and sunscreen compounds [2,5,197-202]. In addition, they have nutritional value to the skin and hair [201]. Therefore, carotenoids are used in both topical treatments, as active ingredients in creams and lotions, and in oral applications via dietary means [201,203]. Although these pigments are spread in all algal phyla, their types are peculiar for each taxonomic group, and they occur in different amounts with variations even among the strains of the same species (for details, see References [2,199]). Carotenoids have different disposition and function in cells, where they can be found in photosynthetic plastids (primary carotenoids) or in the cytoplasm (secondary carotenoids), and they have protective and nutritional functions [10]. Here, it is necessary to also recall that different harvesting techniques and extraction approaches lead to different carotenoids yields, and until now, no single uniform method has been accepted [197,201,204]. 
The best-known UV protectors with dermal topical application and rejuvenating function among the algal carotenoids are astaxanthin (ASX), $\beta$-carotene and lutein $[2,3,6,7,17,197,205-217]$. More than a single contribution could be attributed to these important pigments, all of which are able to decrease hyperpigmentation, while $\beta$-carotene has also a strong provitamin A activity and is applied in the formulation of suntan products, and ASX is valuable for its ability to inhibit skin cancer and to be effective in ulcer prevention [2,4-7,9,10,212].

ASX has gained increasing acceptance due to its beneficial external and internal applications in dermal cosmetics [217]. ASX is available on the market in the forms of cream, powder, soft gel, capsule, tablet, biomass, energy drink, oil and extract, and its products are often made in combination with other carotenoids, multivitamins, herbal extracts and omega-3, 6 fatty acids [218]. There is accumulated evidence, and different patent applications are available on ASX for preventing bacterial infection, inflammation and cancer and improving skin thickness [218]. During clinical studies, ASX suppressed hyperpigmentation with the inhibition of melanin synthesis and photoaging through topical application as a cream (containing also other ingredients) or consuming it as a dietary supplement (single or including tocotrienol from palm oil) [219-223]. Later, clinical studies on female and male subjects demonstrated the improvement of skin conditions in all layers (i.e., corneocyte layer, epidermis, basal layer and dermis) with increased elasticity, decreased age spots and skin wrinkles and diminished trans-epidermal water loss and sebum oil level after combined oral $\left(6 \mathrm{mg}\right.$ day $\left.^{-1}\right)$ and topical application $\left(2 \mathrm{~mL}\right.$ day ${ }^{-1}$ of a 78.9- $\mu \mathrm{M}$ solution) of microalgal ASX (derived from its well-known producer Haematococcus pluvialis) [217]. The authors underlined the positive effects obtained not only in women but also in men and stressed that a combination technique may be very beneficial for the skin. The successful prevention of UV-induced skin damages, such as skin thickening, collagen reduction and increased melanin production, was also achieved using the topical administration of a liposomal formulation containing ASX [224]. An experiment with 40 healthy males demonstrated that the oral bioavailability of ASX increased 1.7-3.7 times when lipid-based formulations were incorporated [32].

ASX, $\beta$-carotene and lutein in different amounts were represented together with 34 other carotenoids in the peculiar class Eustigmatophyceae from the phylum Ochrophyta, for which lutein was reported for first time [199]. Particularly in the strains of its unicellular aeroterrestrial genera Eustigmatos, Monodus and Vischeria, they reached $60-85 \%$ of the total carotenoid content and over $5 \%$ of the dry weight [199]. High $\beta$-carotene and lutein contents were proven in another unicellular alga-the acidophilic $(\mathrm{pH}<2.5)$ green Coccomyxa acidophila, which accumulated up to $3.55 \mathrm{mg} \mathrm{g}^{-1}$ when grown in mixotrophic conditions in the urea [225]. This extremophilic species, which could be efficiently cultivated outdoors, has to be noted especially as a potential commercial lutein source, because it contrasts with the most acidophilic algae, which are slow-growing [225].

The lutein derived from microalgae is in a non-esterified form and, therefore, is an advantageous alternative to conventional plant sources [3]. Regarding the promising microalgal species for lutein production in bioreactors, the analysis of FernándezSevilla et al. [226] revealed two unicellular oleaginous AEM: (1): the green aeroterrestrial Muriellopsis sp., which can produce $4.3-5.5 \mathrm{mg} \mathrm{g}^{-1}$ in a laboratory batch and outdoor tubular systems [227-230], and (2) the acidophilic and aeroterrestrial Auxenochlorella protothecoides (Syn. Chlorella protothecoides) [3,231-237], which is capable of growing both autotrophically and heterotrophically, accumulating large amounts of lipids and lutein especially $\left(4.6 \mathrm{mg} \mathrm{g}^{-1}\right)$ under heterotrophic laboratory growth conditions [225,233]. The aeroterrestrial green unicellular Chromochloris zofingiensis (Syn. Chlorella zofingensis) is able to accumulate high amounts of carotenoids that contain a ketone group, named ketocarotenoids (including ASX, canthaxanthin and lutein), when growing heterotrophically or mixotrophically, or under stress conditions [3,197,200,218,238-246]. Therefore, this species and its Cz-bkt1-5 mutants in particular were suggested as a natural source for the production of zeaxanthin, lutein and $\beta$-carotene [244]. Besides C. zofingiensis, the aeroterrestrial green Neochloris wimmeri, Scenedesmus vacuolatus, Coelastrella oocystiformis (Syn. Scotiellop- 
sis oocystiformis) and Protosiphon botryoides accumulate significant quantities of secondary carotenoids, mainly as ASX esters and canthaxanthin, when grown in conditions of nitrogen deficiency and high light intensity [239]. The proportions of these secondary carotenoids to the rest of the pigments in the green and red cells of these species comprised between $50 \%$ in C. oocystiformis and C. zofingiensis and more than $80 \%$ in Neochloris wimmeri and Protosiphon botryoides, with canthaxanthin predominating in S. vacuolatus [239]. Although being lower than ASX in Haematococcus (22.7 $\mathrm{mg} \mathrm{g}^{-1}$ biomass), the accumulation of this carotenoid reached relatively high values in Neochloris wimmeri, Protosiphon botryoides, Coelastrella oocystiformis, Chromochloris zofingiensis and Scenedesmus vacuolatus of 19.2, 14.3, 10.9, 6.8 and $2.7 \mathrm{mg} \mathrm{g}^{-1}$ biomass, respectively [247]. Evidence has accumulated that Tetradesmus obliquus can synthesize ASX from $\beta$-carotene through three possible pathways, but the accumulation and metabolism of ASX can be controlled by cultivated conditions [248].

Zeaxanthin was found to be abundant $\left(4.26 \mathrm{mg} \mathrm{g}^{-1}\right)$ in the aeroterrestrial green Chlorodium ellipsoideum (Syn. Chlorella ellipsoidea), "with a total level more than nine times that of red pepper, a plant source of zeaxanthin" [249]. The additional value of this microalgal zeaxanthin is its occurrence in the free form, while those in other plants exist as mono- and diesters [249]. Another aeroterrestrial green alga, Coelastrella striolata var. multistriata, is also promising for large-scale cultivation, because it synthesizes very high amounts of major secondary carotenoids (56.0 $\mathrm{mg} \mathrm{g}^{-1}$ biomass) in its reddish-orange cells, with the contents of canthaxanthin, ASX and $\beta$-carotene reaching $47.5,1.5$, and $7.0 \mathrm{mg} \mathrm{g}^{-1}$ cell dry weight, respectively [69].

ASX, zeaxanthin, canthaxanthin and lutein comprise significantly the carotenoid content of aeroterrestrial Chlorella vulgaris and Auxenochlorella pyrenoidosa (Syn. Chlorella pyrenoidosa) [197,205,250-254]. For example, by improving the extraction process, the yield of lutein 3.16-3.36 $\mathrm{mg} \mathrm{g}^{-1}$ (wet weight) from C. vulgaris was achieved [255], or, when saponification was applied, the yield was $85-91 \%$, with the final purity of lutein obtained at 90-98\% [256]. Here, we would like to note that, despite finding strain-specific differences, according to its high total lipid content (58\% dry weight), C. vulgaris was declared as one of the "winners" among the candidates for industrial lipid producers [25,257]. Regarding the possible beneficial effects in dermal cosmetics after oral application, we have to recall that $C$. vulgaris is one of the few microalgae that can be found on the market as a food supplement or additive, food emulsion or colorant (after carotenogenesis) in different forms (capsules, tablets, extracts and powder) (for details, see Reference [24]).

A high lutein content $(0.25 \%)$ with achieved stability of about $90 \%$ was obtained in a developed method for efficient commercial lutein extraction at a lower cost, based on experiments with Tetradesmus obliquus and its strain "Scenedesmus obliquus CNW-N" in particular [258]. Light-related strategies applied to enhance the lutein production of the same species (strain "Scenedesmus obliquus FSP-3") allowed to obtain the optimal productivity of $4.08 \mathrm{mg} \mathrm{L}^{-1} \mathrm{~d}^{-1}$ [259]. Tetradesmus obliquus, with up to a $50 \%$ dry weight lipid content, was also included in the list of "winners" among the microalgal candidates for commercial lipid producers [21,25]. In different cultures of species from the genus Scenedesmus s.l. (from which Tetradesmus was derived), lutein was accumulated as the major carotenoid in the cells, with an achieved increase of lutein and ASX under stress conditions [70,258,260].

Similar results on extremely high ketocarotenoid contents (up to $103 \mathrm{mg}$ total ketocarotenoids $\mathrm{L}^{-1}$ ) with $32 \mathrm{mg}$ ASX L ${ }^{-1}$ were obtained from the specific MA-1 strain of the unicellular green Chlorococcum sp. [261]. It accumulates twice as much as the wild thermotolerant type, which was already proposed for the commercial production of these pigments [261-263]. In the strains of the same species, ASX (in a free form and as esters) was reported together with adonixanthin (in a free form and as esters), lutein, canthaxanthin and $\beta$-carotene $[200,218,264,265]$. Although the total carotenoid content $\left(2 \mathrm{mg} \mathrm{g}^{-1} \mathrm{dw}\right)$ was lower in comparison to the large-scale producer Haematococcus, Chlorococcum, with its higher growth rate, was suggested as a potentially interesting source for secondary carotenoid production [265]. 
A high $\beta$-carotene and lutein content was also reported for the green extremophilic algae developing on snow, such as the cryophilic unicellular Chlorococcum sp. (4.9 mg per $100-\mathrm{g}^{-1}$ fresh mass and $30.1 \mathrm{mg}$ per $100-\mathrm{g}^{-1}$ fresh mass, respectively) and filamentous Raphidonema nivale $\left(5.5 \mathrm{mg}\right.$ per $100-\mathrm{g}^{-1}$ fresh mass and $37.4 \mathrm{mg}$ per $100-\mathrm{g}^{-1}$ fresh mass, respectively) [266]. In samples from reddish and greenish snow, lutein accomplished 77.6 $\left(15.6 \%\right.$ of the total pigment content) and $194.8 \mathrm{mg} \mathrm{g}^{-1}(19.2 \%)$, and $\beta$-carotene reached 11.9 (2\%) and $28.8 \mathrm{mg} \mathrm{g}^{-1}(3 \%)$, respectively [267].

Generally, in red snow with $10^{3}$ to $10^{4}$ red pigmented algal cells $\mathrm{mL}^{-1}$ (mainly Chloromonas alpina, Chloromonas nivalis, Chloromonas polyptera, Raphidonema sempervirens and some uncultured species of Chlamydomonadaceae), the UV-protective secondary carotenoids comprise between 70 and 90\% [66]. Among them, ASX (trans-ASX) dominates [66], as was shown earlier for Chlamydomonas nivalis [268,269]. Similar results on a high ASX content were obtained for the eurythermic and desiccation-resistant red or orange cysts of other green unicellular snow algae, Sanguina nivalis and Sanguina aurantia [270]. ASX was the only pigment detected in the class of secondary carotenoids in Chloromonas polyptera that caused orange snow in the vicinity of penguin rockeries [271]. In the orange cysts of Chloromonas hindakii, ASX comprised 19.8-22.1\% of all the pigments, with amounts comparable to that in Chlamydomonas nivalis $[64,268,269]$. The chemotaxonomical comparison revealed that the high abundance of nonpolar ASX diesters differentiated the green unicellular Chlainomonas, which caused orange snow, from the other two main groups of Chlamydomonadalean snow algae, the "Chloromonas-snow" clade and the "Chlamydomonasred snow" clade [272]. All the evidence accumulated from different studies suggests that the secondary carotenoids like ASX dominate over chlorophylls in green algae snow, which causes red, orange and pink snow during their mass development $[64,268,269,271,273]$ and that these snow algae should be considered valuable sources of these pigments for cosmetic and other industries.

In the red-phase samples of unicellular green snow algae Chlamydomonas nivalis, Chlamydocapsa sp. and Chlorococcum sp., another secondary carotenoid, canthaxanthin, was found to be responsible for their yellow-to-orange pigmentation [266]. The values varied between (12-28)-388 and $921 \mu \mathrm{g} \mathrm{g}^{-1}$ freeze-dried dry mass, being the highest in Chlamydocapsa sp. and Chlorococcum sp. [266]. The relative high content $(65.1 \%)$ of canthaxanthin was detected in the soil cold-tolerant green alga Tetracystis sp., resulting in its dark orange coloration [274]. More recently, this ketocarotenoid was found in four aeroterrestrial oleaginous Visheria / Eustigmatos strains, accounting for 3-7\% of their total carotenoid content [2,199]. Two ketolase genes, $c r t W 38$ and $c r t W 148$, for the heterologous production of canthaxanthin and astaxanthin were cloned from the aeroterrestrial cyanoprokaryote Nostoc punctiforme (strain PCC 73102 [275]). Although its ecophysiological role has to be further clarified, canthaxanthin has been used in tanning products $[2,207,276]$.

$\beta$-carotene was detected as the main carotenoid in a study of 43 strains of the thermophilic red Galdieria sulphuraria, and lutein comprised $0.4 \mathrm{mg} \mathrm{g}^{-1}$, but its total lipid content was low [96]. Similar results on the low lipid content (3-4.6\% weight) contrasting to a high percentage of proteins (22-37\%) and carbohydrates (20-58.4\%) were obtained in a more recent study on biomass composition of this alga grown under heterotrophic conditions $[277,278]$.

Another carotenoid, lycopene, a potent natural antioxidant, is used in personal care formulations as an antiaging agent, and its application as a sunscreen and sunburn-preventing agent has been suggested $[2,207,279]$. Two strains of the aeroterrestrial cyanoprokaryote $\mathrm{An}$ abaena vaginicola contain substantially higher contents of lycopene ( 24.6 and $\left.19.3 \mathrm{mg} \mathrm{g}^{-1} \mathrm{dw}\right)$ in comparison with all the previously reported natural sources [2,280]. The same $A n$ abaena strains and the soil Nostoc calcarea also contained high amounts of $\beta$-carotene (1.2-8.1 $\mathrm{mg} \mathrm{g}^{-1} \mathrm{dry}$ weight) "comparable with the best natural $\beta$-carotene sources" [280]. In all isolated Anabaena and Nostoc strains, lycopene and $\beta$-carotene were combined with lutein and zeaxanthin, which allowed the authors to outline these strains as "rich sources of major carotenoids" [280]. Lycopene in combination with other major carotenoids (1.4\% 
of the ethyl ether extract), namely, $\alpha$-carotene, $\beta$-carotene and $\gamma$-carotene, was isolated in the extremophilic green Dunaliella acidophila [98].

Tocopherols (vitamin E) with their strong antioxidant activity are of special interest for the cosmetics industry $[4,281]$. However, they are relatively rarely studied in microalgae, and only a small amount of data are available on AEM, among which are some aeroterrestrial species belonging to Chlorophyta (Bracteacoccus sp., Coccomyxa sp., Muriella terrestris and Stichococcus bacillaris); Ochrophyta (yellow-green Botrydiopsis intercedens, Heterococcus sp., Xanthonema sp. and eustigmatophycean Monodus guttula) and both green cryophilic species Chlamydocapsa sp. and Raphidonema sempervirens (for details on the amounts, see Reference [2]).

\subsection{Saccharolipids (SL) from AEM}

Saccharolipids (SL) describe compounds in which fatty acids are linked directly to a sugar backbone, forming structures that are compatible with membrane bilayers [33]. However, only a small amount of studies have provided data on SL from microalgae, all of which are from aquatic habitats (for details, see References [10,282]).

\subsection{Polyketides (PK) from AEM}

There are three types of polyketide synthases (PKS; I, II and III) that catalyze the biosynthesis of the structurally and functionally diverse natural products, polyketides (PK) [283]. In general, it is believed that PKS type I is typical for fungi, and type II has been found in bacteria, mitochondria and plastids, while type III occurs mostly in land plants [283]. In algae, type I PKS genes were discovered by genome sequencing but have patchy occurrence, being distributed mostly in green algae [283,284]. Among them, Chlamydomonas reinhardtii, Chlorella variabilis and Coccomyxa subellipsoidea (strain C-169, formerly designated "Coccomyxa sp. C-169") belong to AEM [283-285]. PKS II was discovered in the aeroterrestrial filamentous Klebsormidium flaccidum from Streptophyta and, in unicellular red polyextremophiles inhabitants of acid thermal springs, Cyanidioschyzon merolae and Galdieria sulphuraria [283]. The results from a study of 32 species from different phyla allowed us to demonstrate that PKS I is phylogenetically scattered in algae, suggesting a large potential for the production of PK and non-ribosomal peptides in some phyla, whereas others completely lack this ability [283]. Regarding the safety of cosmetic products, it is necessary to note that PK synthesis plays a role in the biosynthesis of non-ribosomal cyanoprokaryote toxins, namely microcystins, and in some dinoflagellate toxins (for details, see Reference [283]). PKS related to PUFA synthase are involved in the biosynthesis of long-chain polyhydroxy alcohols and contribute to the formation of the glycolipid envelope in specific nitrogen-fixing cells of Cyanoprokaryota known as heterocysts $[75,283,286,287]$.

\subsection{Safety Aspects}

Most compounds included in this review are commonly considered safe and nontoxic, but we have to note that some microalgae can produce toxic metabolites (algal toxins), which are of a great safety concern due to their serious impact on human health (for details, see References [2,35]). From the lipids discussed in the review, PK play a role in the biosynthesis of some algal toxins [283]. Therefore, these lipids and their sources have to be carefully investigated before being utilized in cosmetic products. However, studies oriented towards the checking of algal toxicity are mostly exceptional, and only a few targeted experiments proving the safety of the biomass of oleaginous algae have been conducted [288,289].

Although it has been widely accepted that, among AEM, the number of potential toxin producers is much lower in comparison with their counterparts from aquatic habitats, according to our recent analysis, algal toxins and their producers occur in all general types of detrimental habitats [35]. All nine genera from Cyanoprokaryota, which have been examined for lipids, have already been enlisted among the potential toxin-producers and algae with allergenic potential $[35,290]$. However, due to the lack of precise taxonomic 
information in most publications that address lipid studies, more detailed comparisons are not well-grounded, but we would like to stress the need for specific studies targeted on the toxicity for all novel sources and their products proposed for cosmetical formulations.

\section{Discussion}

The conducted analysis of publications on lipids from AEM issued in the last 56 years showed that most studies addressed PR and FA, specifically carotenoids and FtAs (mainly PUFA), but even these two lipid categories and their accumulation in AEM deserve more attention. In fact, from the eight major groups accepted in LIPID MAPS classification [33,34], only five (i.e., FA, GL, GP, ST, PR and PK) have been examined in different phyla of AEM, as follows: Cyanoprokaryota (FA, GL, ST and PR); Rhodophyta (FA, GL, ST, PR and PK); Ochrophyta (FA, GL and PR); Chlorophyta (FA, GL, GP, ST, PR and PK) and Streptophyta (PK)-Table 1. However, according to the data obtained, it is possible to state that stronger efforts are necessary to improve our knowledge regarding GL, GP and SL and their spread in AEM. Special attention has to be paid to SP, which, according to our best knowledge, remain unknown in AEM.

Table 1. Main lipid classes investigated in aeroterrestrial (AET) and extremophilic (EXT) microalgae of different taxonomic phyla and classes. Abbreviations: AA-arachidonic acid, ASXastaxanthin, DGD—digalactosylglycerol, DGTA—diacylglyceryl-hydroxymethyl- $N, N, N$-trimethyl- $\beta$ Ala, DGTS - diacylglyceryl- $N, N, N$-trimethylhomo-Ser, EPA—eicosapentaenoic acid, FA—fatty acyls, FtAs—fatty acids, FAEs—fatty acid esters, GL—glycerolipids, GP—glycerophospholipids, MGDmonogalactosylglycerol, PC-phosphatidylcholine/lecithin, PE- phosphatidyletanolamine/cephalin, PG—phosphatidylglycerol, PI—phosphatidylinositol, PK—polyketides, PR—prenol lipids, PSphosphatidylserine, PSD—phosphatidylglycerol, SQD—sulphoquinovosyl diacylglycerol, ST—sterol lipids, TGD-triagalactosylglycerol. In Bold are outlined AEM, noted in the cited literature as promising for commercial production and relevant lipids.

\begin{tabular}{|c|c|c|c|}
\hline Taxonomic Group/Alga & Ecological Group & $\begin{array}{l}\text { Investigated Lipid Classes with } \\
\text { Examples of Detected Lipids }\end{array}$ & References \\
\hline \multicolumn{4}{|l|}{ CYANOPROKARYOTA } \\
\hline Anabaena cylindrica & AET & $\begin{array}{c}\text { FA (PUFA-linoleic and linolenic acids, } \\
\text { SAFA—-palmitic acid and MUFA); GL; } \\
\text { ST }\end{array}$ & {$[74]$} \\
\hline Anabaena cylindrica 1403-2 & AET & GL (MGD, DGD, SQD and PSD) & [75] \\
\hline Anabaena vaginicola & AET & $\begin{array}{c}\text { PR (lycopene, lutein, beta-carotene, } \\
\text { zeaxanthin) }\end{array}$ & [280] \\
\hline Calothrix sp. & AET & ST & {$[74,173,187-189]$} \\
\hline Desmonostoc muscorum & AET & $\begin{array}{c}\text { FA (PUFA-hexadecadienoic and } \\
\text { linoleic acids, SAFA—palmitic acid, } \\
\text { MUFA—oleic and palmitoleic acids); } \\
\text { GL;ST }\end{array}$ & {$[74,173,187-189]$} \\
\hline Drouetiella lurida & AET—soil, subaerial & ST (seven unsaturated ST) & [186] \\
\hline Microcoleus autumnalis & AET—soil, subaerial & $\begin{array}{l}\text { ST (cholesterol, } \beta \text {-sitosterol and } \\
\text { stigmasterol with squalene as a } \\
\text { precursor; ergosterol) }\end{array}$ & [189] \\
\hline Nostoc calcarea & AET—soil, subaerial & $\begin{array}{c}\text { PR (lycopene, lutein, beta-carotene, } \\
\text { zeaxanthin) }\end{array}$ & [280] \\
\hline Nostoc calcicola B 1459-2 & AET—soil, subaerial & $\begin{array}{c}\text { FA (PUFA-linolenic acid, SAFA, } \\
\text { MUFA), GL-MGD, DGD, SQD and } \\
\text { PSD }\end{array}$ & [75] \\
\hline
\end{tabular}


Table 1. Cont.

\begin{tabular}{|c|c|c|c|}
\hline Taxonomic Group/Alga & Ecological Group & $\begin{array}{c}\text { Investigated Lipid Classes with Examples } \\
\text { of Detected Lipids }\end{array}$ & References \\
\hline Nostoc carneum & AET—soil, subaerial & ST & {$[74,173,187-189]$} \\
\hline "Nostoc canina" & $\begin{array}{c}\text { AET } \\
\text { (symbiont?) }\end{array}$ & $\begin{array}{l}\text { FA (PUFA - linoleic acid, SAFA -palmitic } \\
\text { acid, MUFA-palmitoleic and oleic acids); } \\
\text { GL; ST (cholesterol and lanosterol) }\end{array}$ & {$[74]$} \\
\hline Nostoc commune & AET & ST & {$[74,173,187-189]$} \\
\hline $\begin{array}{l}\text { Nostoc commune var. } \\
\text { sphaeroides }\end{array}$ & AET & ST (campesterol, sitosterol and clionasterol) & {$[177,188,190]$} \\
\hline Nostoc punctiforme PCC73102 & AET & $\begin{array}{c}\text { FA (FAEs-oxylipins), PR (genes for ASX } \\
\text { and canthaxanthin) }\end{array}$ & {$[115,275]$} \\
\hline Nostoc sp. PCC7120 & AET & FA (FAEs-oxylipins) & {$[116]$} \\
\hline Oscillatoria chalybea B1459-2 & AET & GL (MGD, DGD, TGD, SQD and PSD) & \\
\hline Oscillatoria sp. PBGA3 & AET—soil & FA (FtAs) & {$[76]$} \\
\hline Scytonema sp. & AET & 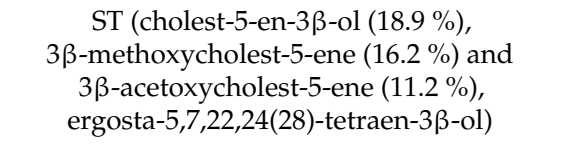 & {$[191]$} \\
\hline Tolypothrix tenuis B1482-3 & AET & GL (MGD, DGD, TGD, SQD and PSD) & {$[75]$} \\
\hline Tolypothrix sp. PBGA1 & AET & FA (FtAs) & {$[76]$} \\
\hline Tolypothrix sp. PBGA2 & AET & FA (FtAs) & [76] \\
\hline \multicolumn{4}{|l|}{ RHODOPHYTA } \\
\hline Cyanidium caldarium & EXT-thermal springs & GL; ST (ergosta-5,7,22,24(28)-tetraen-3 $\beta$-ol) & [192] \\
\hline Cyanidioschyzon merolae & EXT-thermal springs & PK & {$[283]$} \\
\hline $\begin{array}{l}\text { Galdieria sulfuraria (>47 } \\
\text { strains) }\end{array}$ & $\begin{array}{l}\text { EXT—-thermal } \\
\text { springs/AET—cryptoendolith }\end{array}$ & $\begin{array}{l}\text { FA (PUFA-linoleic and linolenic acid, } \\
\text { SAFA-palmitic acid, MUFA-oleic and } \\
\text { palmitoleic acids); GL (MGD, DGD and } \\
\text { SQD; PG, PC, PE, PI, PS and phosphatidate); } \\
\text { GP; ST (ergosta-5,7,22,24(28)-tetraen-3ß-ol } \\
\text { and ergosterol); PR (B-carotene, lutein); PK }\end{array}$ & {$[64,96,128,192,283]$} \\
\hline $\begin{array}{l}\text { Galdieria sulfuraria/Galdieria } \\
\text { sp.? }\end{array}$ & EXT_-acidic but non-thermophilic & $\begin{array}{l}\text { FA (PUFA-linoleic and linolenic acids, } \\
\text { SAFA-palmitic, myristic and stearic acids, } \\
\text { MUFA-oleic and palmitoleic acids) }\end{array}$ & {$[64,96]$} \\
\hline Galdieria sp. USB-GBX-832 & EXT-thermal springs & $\begin{array}{c}\text { FA (PUFA - linoleic acid, AA and EPA; } \\
\text { SAFA — palmitic and stearic acid, } \\
\text { MUFA—oleic acid) }\end{array}$ & [95] \\
\hline Pophyridium purpureum & AET-soil & FA (PUFA-AA and EPA); GL & {$[84]$} \\
\hline \multicolumn{4}{|l|}{$\begin{array}{c}\text { OCHROPHYTA } \\
\text { Eustigmatophyceae }\end{array}$} \\
\hline Monodopsis subterraneus & AET—soil & FA (PUFA-EPA), GL (DGD) & {$[90-94,127]$} \\
\hline Monodus guttula & AET & PR (tocopherols) & {$[2]$} \\
\hline Monodus sp. & AET & $\begin{array}{c}\text { PR (carotenoids-ASX, beta-carotene and } \\
\text { lutein) }\end{array}$ & [199] \\
\hline Vischeria/Eustigmatos & AET—soil, subaerial & $\begin{array}{l}\text { PR (total carotenoids; ASX, beta-carotene, } \\
\text { lutein and canthaxanthin) }\end{array}$ & [199] \\
\hline \multicolumn{4}{|l|}{$\begin{array}{c}\text { Tribophyceae } \\
\text { (=Xanthophyceae) }\end{array}$} \\
\hline Botrydiopsis interdecens & AET & PR (tocopherols) & [2] \\
\hline Heterococcus sp. & AET & PR (tocopherols) & {$[2]$} \\
\hline Xanthonema sp. & AET & PR (tocopherols) & {$[2]$} \\
\hline \multicolumn{4}{|l|}{ CHLOROPHYTA } \\
\hline Acutodesmus dissociatus TGA1 & AET—soil & $\begin{array}{l}\text { FA (SAFA—palmitic acid and MUFA-oleic } \\
\text { acid) }\end{array}$ & {$[76]$} \\
\hline
\end{tabular}


Table 1. Cont.

\begin{tabular}{|c|c|c|c|}
\hline Taxonomic Group/Alga & Ecological Group & $\begin{array}{c}\text { Investigated Lipid Classes with Examples } \\
\text { of Detected Lipids }\end{array}$ & References \\
\hline $\begin{array}{l}\text { Auxenochlorella } \\
\text { protothecoides }\end{array}$ & AET/EXT-acidic & PR (carotenoids-lutein) & {$[231-237]$} \\
\hline Auxenochlorella pyrenoidosa & AET & $\begin{array}{l}\text { PR (carotenoids-ASX, zeaxanthin, } \\
\text { canthaxanthin, lutein) }\end{array}$ & {$[197,205,250,254]$} \\
\hline Bracteacoccus sp. & AET & PR (tocopherols) & [2] \\
\hline Chlamydocapsa sp. & EXT-snow & PR (canthaxanthin, tocopherols) & {$[2,266]$} \\
\hline Chlamydomonas nivalis & EXT-snow & PR (ASX, canthaxanthin) & {$[266,268,269]$} \\
\hline Chlamydomonas reinhardtii & AET & $\begin{array}{c}\text { FA (hydrocarbons-C17 alkene } \\
\text { n-heptadecene), GL (betaine lipids-DGTS); } \\
\text { GP; ST (ergosterol); PK }\end{array}$ & {$[119,131,175,283-285]$} \\
\hline Chlainomonas sp. & EXT-snow & PR (ASX) & {$[272]$} \\
\hline Chlorella sorokiniana & $\mathrm{AET}$ & ST (ergosterol) & {$[175]$} \\
\hline Chlorella variabilis & $\mathrm{AET}$ & PK & {$[283-285]$} \\
\hline Chlorella variabilis NC64A & AET (symbiotic) & ST (ergosterol) & {$[175]$} \\
\hline Chlorella vulgaris & AET & $\begin{array}{c}\text { FA (free FtAs, FAEs-lactones; } \\
\text { hydrocarbons-NC64A eptadecane } \\
\text { pentadecane, as well as 7- and } \\
\text { 8-heptadecene); GL; ST (ergosterol, } \\
\text { 7-dehydroporiferasterol, ergosterol peroxide, } \\
\text { 7-dehydroporiferasterol per-oxide and } \\
\text { 7-oxocholesterol); PR (carotenoids-ASX, } \\
\text { zeaxanthin, canthaxanthin and lutein), PK }\end{array}$ & $\begin{array}{c}{[21,24,101,102,119,195,197} \\
205,250,254]\end{array}$ \\
\hline Chlorella sp. PGA2 & AET—soil & FA (SAFA, MUFA) & {$[76]$} \\
\hline Chlorella sp. TGA2 & AET—soil & FA (SAFA- palmitic acid, MUFA—oleic acid) & [76] \\
\hline Chlorella sp. TGA4 & AET—soil & FA (SAFA, MUFA) & [76] \\
\hline Chlorococcum sp. (1) & AET & $\begin{array}{c}\text { PR (carotenoids-ASX (in a free form and as } \\
\text { esters), adonixanthin (in a free form and as } \\
\text { esters), lutein, canthaxanthin and } \\
\beta \text {-carotene) }\end{array}$ & {$[200,218,261-265]$} \\
\hline Chlorococcum sp. MA-1 & AET & $\begin{array}{l}\text { PR (total carotenoids; ASX, lutein, } \\
\text { canthaxanthin and B-carotene) }\end{array}$ & {$[261]$} \\
\hline Chlorococcum spp. & EXT-snow & PR (ß-carotene, lutein and canthaxanthin) & {$[64,65,266,268,269,271,273]$} \\
\hline Chloroidium ellipsoideum & AET & PR (carotenoids—zeaxanthin) & {$[249]$} \\
\hline Chloromonas alpina & EXT-snow & FA (PUFA, SAFA, MUFA), PR (ASX) & {$[64-67,268,269,271,273]$} \\
\hline Chloromonas hindakii & EXT-snow & $\begin{array}{l}\text { FA (PUFA- } \alpha \text {-linolenic, stereadonic and } \\
\text { hexadecatetraenoic acids, SAFA—palmitic } \\
\text { acid and MUFA-oleic acid); GP; PR (ASX) }\end{array}$ & {$[64-67,268,269,271,273]$} \\
\hline Chloromonas nivalis & EXT-snow & $\begin{array}{c}\text { FA (PUFA-hexadecatetraenoic, SAFA and } \\
\text { MUFA); PR (ASX, canthaxanthin) }\end{array}$ & {$[64-67,266,268,269,271,273]$} \\
\hline $\begin{array}{c}\text { Chloromonas nivalis subsp. } \\
\text { tatrae }\end{array}$ & EXT-snow & FA (PUFA, SAFA and MUFA); PR (ASX) & {$[67]$} \\
\hline Chloromonas polyptera & EXT-snow & FA (PUFA, SAFA and MUFA), PR (ASX) & {$[64-67,268,269,271,273]$} \\
\hline $\begin{array}{l}\text { Chloromonas remiasii } \\
\text { CCCryo 005-99 }\end{array}$ & EXT-snow & $\begin{array}{c}\text { FA (PUFA-hexadecatetraenoic acid, SAFA } \\
\text { and MUFA), PR }\end{array}$ & {$[63-67,268,269,271,273]$} \\
\hline Chloromonas spp. & EXT-snow & $\begin{array}{c}\text { FA (PUFA, SAFA—palmitic acid and } \\
\text { MUFA—oleic acid), PR }\end{array}$ & {$[65-67,268,269,271,273]$} \\
\hline Chromochloris zofingiensis & AET & $\begin{array}{l}\text { PR (carotenoids-ASX, canthaxanthin, } \\
\text { zeaxanthin, lutein and } \beta \text {-carotene) }\end{array}$ & {$[197,200,218,238-247]$} \\
\hline Coccomyxa acidophila & EXT-acidic & PR (carotenoids-B-carotene and lutein) & {$[255]$} \\
\hline Coccomyxa subellipsoidea & AET & ST (phytosterols) & {$[175]$} \\
\hline Coccomyxa subellipsoidea C-169 & AET & PK & {$[283-285]$} \\
\hline
\end{tabular}


Table 1. Cont.

\begin{tabular}{|c|c|c|c|}
\hline Taxonomic Group/Alga & Ecological Group & $\begin{array}{l}\text { Investigated Lipid Classes with Examples } \\
\text { of Detected Lipids }\end{array}$ & References \\
\hline Coccomyxa sp. & AET & PR (tocopherols) & [2] \\
\hline Coelastrella oocystiformis & AET & $\begin{array}{l}\text { PR (carotenoids-ASX esters and } \\
\text { canthaxanthin) }\end{array}$ & {$[239,247]$} \\
\hline $\begin{array}{l}\text { Coelastrella striolata var. } \\
\text { multistriolata }\end{array}$ & AET—subaerial, soils & $\begin{array}{c}\text { FA (PUFA-linoleic acid, SAFA-palmitic } \\
\text { acid and MUFA-oleic acid); PR } \\
\text { (carotenoids-canthaxanthin, ASX and } \\
\text { B-carotene) }\end{array}$ & {$[68,69]$} \\
\hline Dunaliella acidophila & EXT-acidic & $\begin{array}{l}\text { FA (PUFA-linolenic, } \gamma \text {-linolenic and } \\
\text { linoleic acids; SAFA; MUFA-oleic and } \\
\text { elaidic acids; FAEs-lactones, methyl (12R)- } \\
\text { hydroxyoctadeca-9Z,13E,15Z-trienoate, } \\
\text { methyl (9S)-hydroxyoctadeca-10E, } \\
\text { 12Z,15Z-trienoate and methyl ricinoleate; } \\
\text { triacylglycerols-trilinolenin, triolein, } \\
\text { trielaidin and tristearin); ST ( } \beta \text {-sitosterol, } \\
\text { isofucosterol, 24-methylenlophenol, } \\
\text { (24S)-methyllophenol and two unidentified } \\
\text { sterols, acylsterols and phytol); PR } \\
\text { (lycopene, alpha-, beta and gamma-carotene) }\end{array}$ & {$[98,119]$} \\
\hline Edaphochlamys debaryana & AET—soil & FA (FAEs—oxylipins) & [112] \\
\hline Hindakia tetrachotoma PGA1 & AET—soil & $\begin{array}{l}\text { FA (SAFA—palmitic acid and MUFA—oleic } \\
\text { acid) }\end{array}$ & [76] \\
\hline Monoraphidum sp. & EXT-ice & FA (PUFA) & [31] \\
\hline Muriella terrestris & AET & PR (tocopherols) & [2] \\
\hline Muriellopsis sp. & AET & PR (carotenoids-lutein) & [226-230] \\
\hline Neochloris wimmeri & AET & $\begin{array}{l}\text { PR (carotenoids_-ASX esters and } \\
\text { canthaxanthin) }\end{array}$ & {$[239,247]$} \\
\hline Parietochloris alveolaris & AET—oil, symbiont & $\begin{array}{c}\text { FA (PUFA-EPA, AA and its precursor } \\
\text { dihomo- } \gamma \text {-linolenic acid) }\end{array}$ & {$[80,82]$} \\
\hline Parietochloris alveolaris K-1 & AET & FA (PUFA- $-\alpha$-linolenic acid and EPA) & {$[78,79]$} \\
\hline Protosiphon botryoides & AET—soil & $\begin{array}{l}\text { PR (carotenoids-ASX esters and } \\
\text { canthaxanthin) }\end{array}$ & {$[239,247]$} \\
\hline $\begin{array}{c}\text { Pseudochoricystis } \\
\text { ellipsoidea MBIC11204 }\end{array}$ & EXT—-thermal springs & $\begin{array}{l}\text { FA (FtAs and FAEs—hydrocarbons and } \\
\text { triacylglycerols) }\end{array}$ & [122] \\
\hline Raphidonema sempervirens & EXT—snow & $\begin{array}{c}\text { FA (PUFA, SAFA and MUFA); PR } \\
\text { (B-carotene, ASX, lutein and tocopherols) }\end{array}$ & {$[2,65-67,266]$} \\
\hline Sanguina aurantia & EXT—snow & PR (ASX) & [270] \\
\hline Sanguina nivalis & EXT—snow & PR (ASX) & [270] \\
\hline Scenedesmus vacuolatus & AET & $\begin{array}{l}\text { PR (carotenoids-ASX esters and } \\
\text { canthaxanthin) }\end{array}$ & {$[239,247]$} \\
\hline Scenedesmus spp. & AET & PR (total carotenoids, ASX and lutein) & {$[69,258,260]$} \\
\hline Stichococcus bacillaris & AET & PR (tocopherols) & [2] \\
\hline Tetracystis sp. & AET/EXT_cryotolerant & PR (canthaxanthin) & [274] \\
\hline Tetradesmus obliquus & AET & $\begin{array}{c}\text { FA (PUFA-linolenic, linoleic and } \\
\text { linolelaidic acids and SAFA—oleic acid); PR } \\
\text { (carotenoids-ASX and lutein) }\end{array}$ & {$[21,25,69-73,248,258,260]$} \\
\hline $\begin{array}{l}\text { Tetradesmus obliquus (strain } \\
\text { Scenedesmus obliquus SNW-N) }\end{array}$ & AET & PR (lutein) & [258] \\
\hline $\begin{array}{l}\text { Tetradesmus obliquus (strain } \\
\text { Scenedesmus obliquus FSP-3) }\end{array}$ & AET & PR (lutein) & [259] \\
\hline Ulothrix zonata & EXT-ice & FA (PUFA) & [68] \\
\hline $\begin{array}{c}\text { "Unidentified } \\
\text { Chlamydomonadaceae" }\end{array}$ & EXT—snow & FA (PUFA, SAFA and MUFA); PR (ASX) & [76] \\
\hline
\end{tabular}


Table 1. Cont.

\begin{tabular}{ccc}
\hline Taxonomic Group/Alga & Ecological Group & $\begin{array}{c}\text { Investigated Lipid Classes with Examples } \\
\text { of Detected Lipids }\end{array}$ \\
\hline $\begin{array}{c}\text { Unidentified } \\
\text { “Chlamydomonadales } \\
\text { species" TGA3 }\end{array}$ & AET_-soil, thermotolerant & FA (SAFA and MUFA) \\
$\begin{array}{c}\text { Unidentified } \\
\text { "Chlamydomonadales } \\
\text { species” TGA5 }\end{array}$ & AET_-soil & FA (SAFA and MUFA) \\
\hline STREPTOPHYTA & [76] & \\
\hline Klebsormidium flaccidum & AET & PK \\
\hline
\end{tabular}

The taxonomic diversity of the examined AEM, expressed by the number of species, is as follows: Cyanoprokaryota-20, Rhodophyta-6, Ochrophyta-7, Chlorophyta-53 and Streptophyta-1 (Figure $1 \mathrm{~A}$ and Table 1). Thus, AEM from green evolutionary lineages (Chlorophyta and Streptophyta) are the most investigated, but a strong discrepancy between the studies inside the green lineages is obvious, with only one species from Streptophyta (i.e., Klebsormidium flaccidum) investigated in comparison with 53 species of 34 genera from Chlorophyta. The next most-studied group is represented by prokaryotic blue-green algae, Cyanoprokaryota, from which 20 species of nine genera have been analyzed. The number of species investigated in Rhodophyta and Ochrophyta is significantly lower and almost similar (six and seven, respectively), but more genera have been covered by studies on Ochrophyta (seven) than from Rhodophyta (four). However, much more strains from Rhodophyta have been examined, with more than 47 strains investigated from a single species (i.e., the extremophilic Galdieria sulfuraria). Most of the studied AEM are unicellular (59), followed by filamentous (26) and coenobial algae (2). The highest morphological diversity has been found in the studied chlorophyte algae, while, from Cyanoprokaryota, only filamentous species and, from Rhodophyta, only unicellular species were examined for different lipids.

Regarding the ecological affiliation of the examined microalgae (Figure 1B,C), it could be stated that the highest number (66) of studied species are aeroterrestrial, and they are the most taxonomically diverse, including representatives from all five major algal phyla (Figure 1C). By contrast, the number of examined extremophilic species is lower (21), with only two phyla studied (i.e., Rhodophyta and Chlorophyta) (Figure 1B). Despite this generally low number, ten extremophilic algae (ca. 50\%) have been considered as promising lipid sources (Table 1). However, it has to be boldly underlined that this analysis is based only on Latin species names provided in the available publications, since, for most of the strains, there are neither data from genetic studies nor detailed morphological and ecological descriptions. In the recent times of rapid taxonomical changes, providing such data in future publications is strongly recommended in order to obtain more precise information on the biochemical compositions of the studied microalgae. 

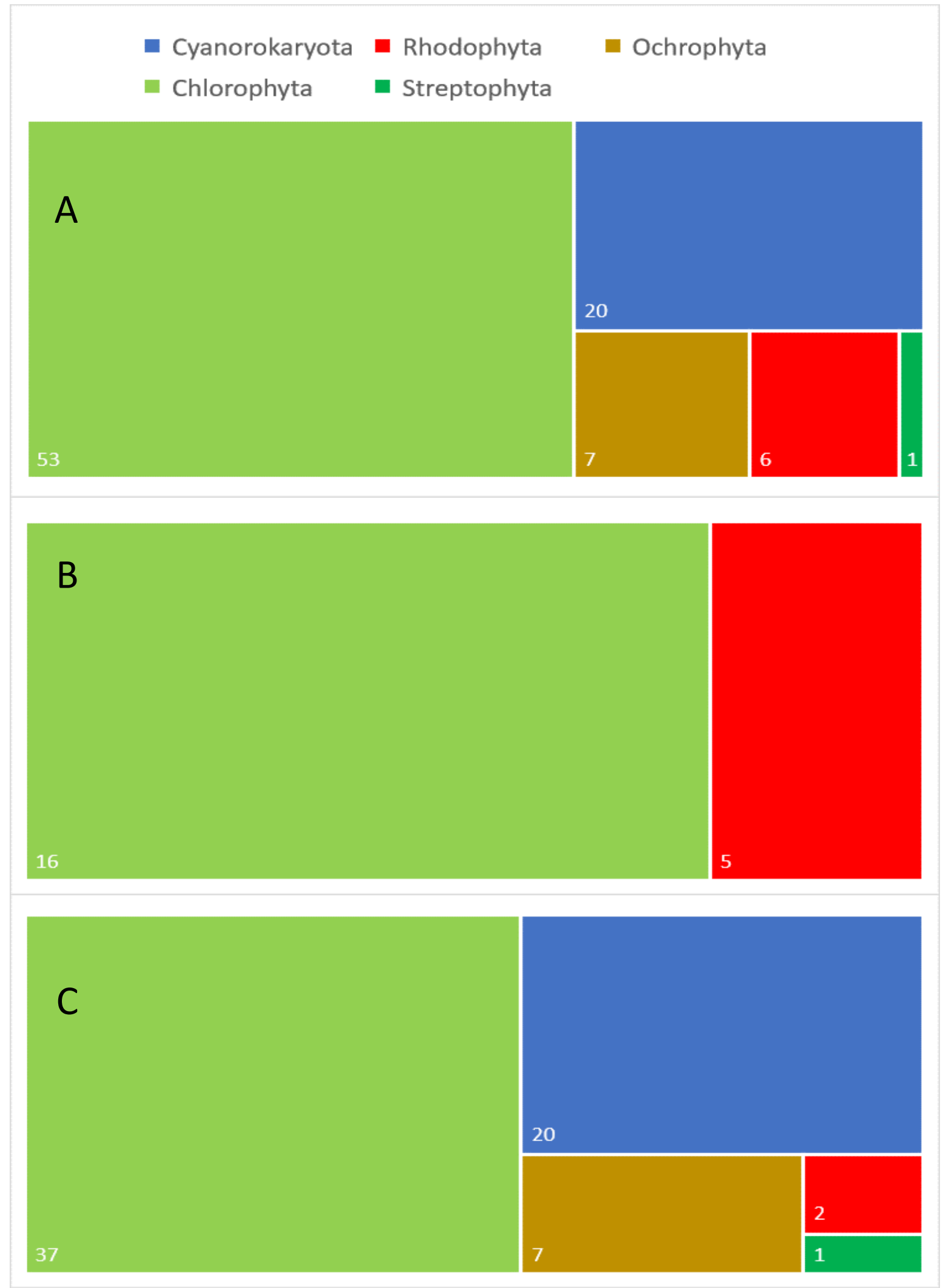

Figure 1. Taxonomic diversity of aeroterrestrial and extremophilic microalgae analyzed for different lipids: (A) general taxonomic diversity of the analyzed algal species, (B) taxonomic diversity of the examined extremophilic species and $(\mathbf{C})$ taxonomic diversity of the investigated aeroterrestrial species. Numbers in white indicate the exact number in each category. 
The results obtained clearly showed that very few known AEM have been investigated for their lipid content, with most of the studies being quite scarce and oriented towards certain compounds. Less studies were comparative, but the differences in lipid contents were demonstrated with field materials and cultivated in different conditions algae, or ecologically different strains (e.g., thermophilic and non-thermophilic) were investigated. These results may stimulate further research for the best physiological and cultural conditions, which would lead to the optimal yield of algal biomass and certain lipids. As we have shown in the text above, data on all lipid classes in AEM are far away from being complete, and more investigations on certain compounds and in more AEM are needed in the future. Nevertheless, all collected evidence until now suggests the great potential of AEM as novel commercial lipid sources for versatile cosmetic substances and products for skin care. In this regard AEM are comparable with their aquatic (marine and freshwater) counterparts and land plants, which have been much more intensively studied [1,2,291]. Twenty-three AEM have been already pointed out as promising for obtaining certain compounds, most of them from Chlorophyta (Table 1). The potential of AEM as beneficial lipid sources can be recognized in two aspects, separately or in combination: (1) quantitative, since, in some AEM, the contents of valuable lipids are higher in comparison with other algae or plants (e.g., Parietochloris alveolaris is considered to be the richest natural source of the high value polyunsaturated w6 AA, or Chlorodium ellipsoideum, in which zeaxanthin exceeded more than nine times that of red pepper, a plant source of zeaxanthin) and (2) qualitative, since, in some AEM, rare and unusual lipids were discovered (e.g., the three hydroxy FtAs in Dunaliella acidophila, such as methyl (12R)-hydroxyoctadeca-9Z,13E,15Z-trienoate, methyl (9S)-hydroxyoctadeca-10E, 12Z,15Z-trienoate and methyl ricinoleate, or the unidentified ST of Scytonema sp. and Dunaliella acidophila). These compositional peculiarities in AEM, as it has been shown earlier, are due to their specific ecology and adaptations to survive inimically in other organism environments, and this potential is still untapped [2]. However, among the AEM examined for lipids occur species from genera that have already been recognized as potential toxin producers or allergic-causative agents [34,290]. On that account, in order to answer safety concerns, we strongly underline that all algae, chosen as lipid sources for direct use or for transformation to LNP, must be subjected to chemical analyses before introducing them into mass cultures and cosmetics formulations.

\section{Conclusions}

The cosmetics industry is increasingly exploring new compounds derived from natural products, preferably from plant origins, due to strong consumer demands [2,291]. In addition, nanotechnologies are delving deeper into people's lives, including the field of skin cosmetics [16]. It is well-known that skin lipid compositions and structures are significant for proper skin functioning, and their deficit leads to skin diseases and disorders [9-11]. Therefore, in addition to traditional topical and oral lipid applications, there is a rising interest in enhancing the targeted lipid transport to different skin layers using nanosized systems, including LNP [12-19]. Currently, different methods for obtaining nanoparticles from lipids have been developed and standardized [14,19]. Since algae from different ecological and taxonomic groups are rich in biologically active compounds, including lipids, they are increasingly becoming the focus of biotechnology [1-8]. However, to date, mostly aquatic micro- and macroalgae have been investigated, whereas the algae from aeroterrestrial and versatile extremophilic habitats have been more neglected. At the same time, due to their peculiar ecology, AEM produce many specific compounds that are not available from other algae or accumulate higher amounts of other chemicals than other algae and plants [2]. To the best of our knowledge, there are no commercially produced skin care preparations, or LNP, yet based on lipids from AEM, despite some AEM being outlined as promising commercial lipid sources (Table 1). Therefore, we summarized the available, but quite scattered, data on the lipid contents of different species of AEM issued during the last 56 years. 
According to the analysis of this knowledge, considering: (1) the successes in the clinical experiments for the treatment, alleviation or prevention of different skin disorders, as well as all other beneficial effects of versatile lipids, which occur in AEM; (2) the fact that both standard and unusual lipids have been detected, and most of them can be obtained in profitable amounts from AEM; (3) the possibilities to benefit from the direct application of lipids or from their enhanced penetration using LNP; (4) the developed methods for obtaining LNP [13]; (5) the advantages of the effective mass cultivation of AEM species even outdoor, unfavorable for algae from "standard" aquatic habitats, conditions, which can make more cost-effective and beneficial yields of both unusual and standard lipids; (6) the gradually increasing phycoprospection in the background of the enormous biodiversity of microalgae, which has been recognized but is far away from being utilized, we believe that all the provided data will serve as the groundwork to enhance and further encourage studies for broader applications of AEM-derived lipids in novel products of the future dermal cosmetics bioindustry.

Author Contributions: Conceptualization, M.S.-G.; writing—original draft preparation, M.S.-G.; writing-review and editing, M.S.-G., B.U. and G.G.; visualization, M.S.-G.; project administration, B.U. and funding acquisition, B.U. All authors have read and agreed to the published version of the manuscript.

Funding: This research was funded by the Scientific Research Fund of the Bulgarian Ministry of Education, grant number DN-13-9/15.12.2017.

Institutional Review Board Statement: Not applicable.

Informed Consent Statement: Not applicable.

Data Availability Statement: Not applicable.

Conflicts of Interest: The authors declare no conflict of interest.

\section{References}

1. Ariede, M.B.; Candido, T.M.; Jacome, A.L.M.; Velasco, M.V.R.; de Carvalho, J.C.M.; Baby, A.R. Cosmetic attributes of algae-A review. Algal Res. 2017, 25, 483-487. [CrossRef]

2. Stoyneva-Gärtner, M.; Uzunov, B.; Gärtner, G. Enigmatic microalgae from aeroterrestrial and extreme habitats in cosmetics: The potential of the untapped natural sources. Cosmetics 2020, 7, 27. [CrossRef]

3. Sun, Z.; Li, T.; Zhou, Z.; Jiang, Y. Microalgae as a source of lutein: Chemistry, biosynthesis, and carotenogenesis. In Microalgae Biotechnology. Advances in Biochemical Engineering/Biotechnology; Posten, C., Feng, C.S., Eds.; Springer: Cham, Switzerland, 2016; Volume 153, pp. 37-58. [CrossRef]

4. Joshi, S.; Kumari, R.; Upasani, V.N. Applications of algae in cosmetics: An overview. Int. J. Innov. Res. Sci. Eng. Technol. 2018, 7, 1269-1278. [CrossRef]

5. Jahan, A.; Ahmad, I.Z.; Fatima, N.; Ansari, V.A.; Akhtar, J. Algal bioactive compounds in the cosmeceutical industry: A review. Phycologia 2017, 56, 410-422. [CrossRef]

6. Wang, H.M.D.; Chen, C.C.; Huynh, P.; Chang, J.S. Exploring the potential of using algae in cosmetics. Bioresour. Technol. 2015, 184, 355-362. [CrossRef] [PubMed]

7. Basily, H.S.; Nassar, M.M.; Diwani, G.I.; Abo El-Enin, S.A. Exploration of using the algal bioactive compounds for cosmeceuticals and pharmaceutical applications. Egypt. Pharm. J. 2018, 17, 109-120. Available online: http://www.epj.eg.net/text.asp?2018/17/ 2/109/240673 (accessed on 25 November 2021).

8. Rastogi, R.P.; Sinha, R.P. Biotechnological and industrial significance of cyanobacterial secondary metabolites. Biotechnol. Adv. 2009, 27, 521-539. [CrossRef]

9. Bonnet, C. Lipids, a natural raw material at the heart of cosmetics innovation. OCL 2018, 25, D501. [CrossRef]

10. De Luca, M.; Pappalardo, I.; Limongi, A.R.; Viviano, E.; Radice, R.P.; Todisco, S.; Martelli, G.; Infantino, V.; Vassallo, A. Lipids from microalgae for cosmetic applications. Cosmetics 2021, 8, 52. [CrossRef]

11. Knox, S.; O'Boyle, N.M. Skin lipids in health and disease: A review. Chem. Phys. Lipids 2021, 236, 105055. [CrossRef] [PubMed]

12. Kabri, T.; Arab-Tehrany, E.; Belhaj, N.; Linder, M. Physico-chemical characterization of nano-emulsions in cosmetic matrix enriched on omega-3. J. Nanobiotechnol. 2011, 9, 41. [CrossRef] [PubMed]

13. Sarkar, R.D.; Singh, H.B.; Kalita, M.C. Enhanced lipid accumulation in microalgae through nanoparticle-mediated approach, for biodiesel production: A mini-review. Heliyon 2021, 7, e08057. [CrossRef]

14. Khater, D.; Nsairat, H.; Odeh, F.; Saleh, M.; Jaber, A.; Alshaer, W.; Al Bawab, A.; Mubarak, M.S. Design, preparation, and characterization of effective dermal and transdermal lipid nanoparticles: A review. Cosmetics 2021, 8, 39. [CrossRef] 
15. Smijs, T.G.; Pavel, S. Titanium dioxide and zinc oxide nanoparticles in sunscreens: Focus on their safety and effectiveness. Nanotechnol. Sci. Appl. 2011, 4, 95. [CrossRef] [PubMed]

16. Khezri, K.; Saeedi, M.; Dizaj, S.M. Application of nanoparticles in percutaneous delivery of active ingredients in cosmetic preparations. Biomed. Pharmacother. 2018, 106, 1499-1505. [CrossRef]

17. Alvarez, A.M.R.; Rodríguez, M.L.G. Lipids in pharmaceutical and cosmetic preparations. Grasas Aceites 2000, 51, 74-96. Available online: https:/ / grasasyaceites.revistas.csic.es/index.php/grasasyaceites/article/view/409 (accessed on 3 November 2021).

18. Zielinska, A.; Nowak, I. Fatty acids in vegetable oils and their importance in cosmetic industry. CHEMIK Nauka Tech. Rynek 2014, $68,103-110$.

19. Ahmad, J. Lipid nanoparticles based cosmetics with potential application in alleviating skin disorders. Cosmetics $2021,8,84$. [CrossRef]

20. Patel, A.; Karageorgou, D.; Rova, E.; Katapodis, P.; Rova, U.; Christakopoulos, P.; Matsakas, L. An overview of potential oleaginous microorganisms and their role in biodiesel and omega-3 fatty acid-based industries. Microorganisms 2020, 8, 434. [CrossRef]

21. Mata, T.M.; Martins, A.A.; Caetano, N.S. Microalgae for biodiesel production and other applications: A review. Renew. Sustain. Energy Rev. 2010, 14, 217-232. [CrossRef]

22. Spolaore, P.; Joannis-Cassan, C.; Duran, E.; Isambert, A. Commercial applications of microalgae. J. Biosci. Bioeng. 2006, 101, 87-96. [CrossRef]

23. McKie-Krisberg, Z.M.; Laurens, L.M.L.; Huang, A.; Polle, J.E.W. Comparative energetics of carbon storage molecules in green algae. Algal Res. 2018, 31, 326-333. [CrossRef]

24. Safi, C.; Zebib, B.; Merah, O.; Pontalier, P.-Y.; Vaca-Garcia, C. Morphology, composition, production, processing and applications of Chlorella vulgaris: A review. Renew. Sustain. Energy Rev. 2014, 35, 265-278. [CrossRef]

25. Pignolet, O.; Jubeau, S.; Vaca-Garcia, C.; Philippe, M. Highly valuable microalgae: Biochemical and topological aspects. J. Ind. Microbiol. Biotechnol. 2013, 40, 781-796. [CrossRef] [PubMed]

26. Wilkie, A.C.; Edmundson, S.J.; Duncan, J.G. Indigenous algae for local bioresource production: Phycoprospecting. Energy Sustain. Dev. 2011, 15, 365-371. [CrossRef]

27. Stoyneva-Gärtner, M.; Uzunov, B.; Gärtner, G.; Radkova, M.; Atanassov, I.; Atanassova, R.; Borisova, C.; Draganova, P.; Stoykova, P. Review on the biotechnological and nanotechnological potential of the streptophyte genus Klebsormidium with pilot data on its phycoprospecting and polyphasic identification in Bulgaria. Biotechnol. Biotechnol. Equip. 2019, 33, 559-578. [CrossRef]

28. Aratboni, H.A.; Rafiei, N.; Garcia-Granados, R.; Alemzadeh, A.; Morones-Ramírez, J.R. Biomass and lipid induction strategies in microalgae for biofuel production and other applications. Microb. Cell Fact. 2019, 18, 178. [CrossRef]

29. Slocombe, S.P.; Zhang, Q.Y.; Ross, M.; Anderson, A.; Thomas, N.J.; Lapresa, Á.; Rad-Menéndez, C.; Campbell, C.N.; Black, K.D.; Stanley, M.S.; et al. Unlocking nature's treasure-chest: Screening for oleaginous algae. Sci. Rep. 2015, 5, 9844. [CrossRef]

30. Richter, C.K.; Skulas-Ray, A.C.; Kris-Etherton, P.M. Recommended intake of fish and fish oils worldwide. In Fish and Fish Oil in Health and Disease Prevention; Raatz, S.K., Bibus, D.M., Eds.; Elsevier: London, UK, 2016; pp. 27-48. [CrossRef]

31. ̌ezanka, T.; Nedbalová, L.; Lukavský, J.; Stř́žek, A.; Sigler, K. Pilot cultivation of the green alga Monoraphidium sp. producing a high content of polyunsaturated fatty acids in a low-temperature environment. Algal Res. 2017, 22, 160-165. [CrossRef]

32. Odeberg, M.J.; Lignell, A.; Pettersson, A.; Hoglund, P. Oral bioavailability of the antioxidant astaxanthin in humans is enhanced by incorporation of lipid-based formulations. Eur. J. Pharm. Sci. 2003, 19, 299-304. [CrossRef]

33. Fahy, E.; Subramaniam, S.; Brown, H.A.; Glass, C.K.; Merrill, A.H.; Murphy, R.C.; Raetz, C.R.H.; Russell, D.W.; Seyama, Y.; Shaw, W.; et al. A comprehensive classification system for lipids. J. Lipid Res. 2005, 46, 839-861. [CrossRef] [PubMed]

34. Fahy, E.; Subramaniam, S.; Murphy, R.C.; Nishijima, M.; Raetz, C.R.H.; Shimizu, T.; Spener, F.; van Meer, G.; Wakelam, M.J.O.; Dennis, E.A. Update of the LIPID MAPS comprehensive classification system for lipids. J. Lipid Res. 2009, 50, S9-S14. [CrossRef] [PubMed]

35. Gärtner, G.; Stoyneva-Gärtner, M.; Uzunov, B. Algal toxic compounds and their aeroterrestrial, airborne and other extremophilic producers with attention to soil and plant contamination: A review. Toxins 2021, 13, 322. [CrossRef] [PubMed]

36. Guiry, M.D.; Guiry, G.M. AlgaeBase. World-Wide Electronic Publication; National University of Ireland: Galway, Ireland, 2020. Available online: https:/ / www.algaebase.org (accessed on 26 November 2021).

37. Maltsev, Y.; Maltseva, K. Fatty acids of microalgae: Diversity and applications. Rev. Environ. Sci. Biotechnol. 2021, 20, 515-547. [CrossRef]

38. Barkia, I.; Saari, N.; Manning, S.R. Microalgae for high-value products towards human health and nutrition. Mar. Drugs 2019, 17, 304. [CrossRef] [PubMed]

39. Yang, M.; Zhou, M.; Song, L. A review of fatty acids influencing skin condition. J. Cosmet. Dermatol. 2020, 19, 3199-3244 [CrossRef] [PubMed]

40. Kaur, N.; Chugh, V.; Gupta, A.K. Essential fatty acids as functional components of foods-a review. J. Food Sci. Technol. 2014, 51, 2289-2303. [CrossRef] [PubMed]

41. Jandacek, R.J. Linoleic acid: A nutritional quandary. Healthcare 2017, 5, 25. [CrossRef]

42. Ziboch, V.A.; Miller, C.C.; Cho, Y. Metabolism of polyunsaturated fatty acids by skin epidermal enzymes: Generation of antiinflammatory and antiproliferative metabolites. Am. J. Clin. Nutr. 2000, 71, 361s-366s. [CrossRef] [PubMed] 
43. Huang, T.-H.; Wang, P.-W.; Yang, S.-C.; Chou, W.-L.; Fang, J.-Y. Cosmetic and therapeutic applications of fish oil's fatty acids on the skin. Mar. Drugs 2018, 16, 256. [CrossRef]

44. Bojarowicz, H.; Makowska, K.; Krysiński, J. Polyunsaturated fatty acids in diet for general health and skin care. Nutr. Food Sci. Int. J. 2019, 8, 555750. [CrossRef]

45. Horrobin, D.F. Essential fatty acid metabolism and its modification in atopic eczema. Am. J. Clin. Nutr. 2000, 71, 367s-372s. [CrossRef] [PubMed]

46. Ekanayake-Mudiyanselage, S.; Aschauer, H.; Schmook, F.P.; Jensen, J.M.; Meingassner, J.G.; Proksch, E. Expression of epidermal keratins and the cornified envelope protein involucrin is influenced by permeability barrier disruption. J. Investig. Dermatol. 1998, 111, 517-523. [CrossRef] [PubMed]

47. Meguro, S.; Arai, Y.; Masukawa, Y.; Uie, K.; Tokimitsu, I. Relationship between covalently bound ceramides and transepidermal water loss (TEWL). Arch. Dermatol. Res. 2000, 292, 463-468. [CrossRef]

48. Cardoso, C.R.B.; Souza, M.A.; Ferro, E.A.V.; Favoreto, S.; Pena, J.D.O. Influence of topical administration of n-3 and n-6 essential and n-9 nonessential fatty acids on the healing of cutaneous wounds. Wound Repair Regen. 2004, 12, 235-243. [CrossRef]

49. Calder, P.C. Mechanisms of action of (n-3) fatty acids. J. Nutr. 2012, 142, 592s-599s. [CrossRef]

50. Balcos, M.C.; Kim, S.Y.; Jeong, H.S.; Yun, H.Y.; Baek, K.J.; Kwon, N.S.; Park, K.C.; Kim, D.S. Docosahexaenoic acid inhibits melanin synthesis in murine melanoma cells in vitro through increasing tyrosinase degradation. Acta Pharmacol. Sin. 2014, 35, 489-495. [CrossRef]

51. Ando, H.; Ryu, A.; Hashimoto, A.; Oka, M.; Ichihashi, M. Linoleic acid and $\alpha$-linolenic acid lightens ultraviolet-induced hyperpigmentation of the skin. Arch. Dermatol. Res. 1998, 290, 375-381. [CrossRef]

52. Ando, H.; Funasaka, Y.; Oka, M.; Ohashi, A.; Furumura, M.; Matsunaga, J.; Matsunaga, N.; Hearing, V.J.; Ichihashi, M. Possible involvement of proteolytic degradation of tyrosinase in the regulatory effect of fatty acids on melanogenesis. J. Lipid Res. 1999, 40, 1312-1316. [CrossRef]

53. Pereira, L.M.; Hatanaka, E.; Martins, E.F.; Oliveira, F.; Liberti, E.A.; Farsky, S.H.; Curi, R.; Pithon-Curi, T.C. Effect of oleic and linoleic acids on the inflammatory phase of wound healing in rats. Cell Biochem. Funct. 2008, 26, 197-204. [CrossRef]

54. Rodrigues, H.G.; Vinolo, M.A.R.; Sato, F.T.; Magdalon, J.; Kuhl, C.M.C.; Yamagata, A.S.; Pessoa, A.F.M.; Malheiros, G.; dos Santos, M.F.; Lima, C.; et al. Oral administration of linoleic acid induces new vessel formation and improves skin wound healing in diabetic rats. PLoS ONE 2016, 11, e0165115. [CrossRef]

55. Wu, D.C.; Goldman, M.P. A topical anti-inflammatory healing regimen utilizing conjugated linolenic acid for use post-ablative laser resurfacing of the face: A randomized, controlled trial. J. Clin. Aesthet. Dermatol. 2017, 10, 12-17.

56. Kiecolt-Glaser, J.K.; Glaser, R.; Christian, L.M. Omega-3 fatty acids and stress-induced immune dysregulation: Implications for wound healing. Mil. Med. 2014, 179 (Suppl. 11), 129-133. [CrossRef] [PubMed]

57. Chung, S.; Kong, S.; Seong, K.; Cho, Y. $\gamma$-Linolenic acid in borage oil reverses epidermal hyperproliferation in guinea pigs. J. Nutr. 2002, 132, 3090-3097. [CrossRef] [PubMed]

58. Brosche, T.; Platt, D. Effect of borage oil consumption on fatty acid metabolism, transepidermal water loss and skin parameters in elderly people. Arch. Gerontol. Geriatr. 2000, 30, 139-150. [CrossRef]

59. McCusker, M.M.; Grant-Kels, J.M. Healing fats of the skin: The structural and immunologic roles of the omega-6 and omega-3 fatty acids. Clin. Dermatol. 2010, 28, 440-451. [CrossRef]

60. Feingold, K.R. The role of epidermal lipids in cutaneous permeability barrier homeostasis. J. Lipid Res. 2007, 48, 2531-2546. [CrossRef]

61. Shingel, K.I.; Faure, M.P.; Azoulay, L.; Roberge, C.; Deckelbaum, R.J. Solid emulsion gel as a vehicle for delivery of polyunsaturated fatty acids: Implications for tissue repair, dermal angiogenesis and wound healing. J. Tissue Eng. Regen. Med. 2008, 2, 383-393. [CrossRef]

62. Shigeta, Y.; Imanaka, H.; Ando, H.; Ryu, A.; Oku, N.; Baba, N.; Makino, T. Skin whitening effect of linoleic acid is enhanced by liposomal formulations. Biol. Pharm. Bull. 2004, 27, 591-594. [CrossRef]

63. Spijkerman, E.; Wacker, A.; Weithoff, G.; Leya, T. Elemental and fatty acid composition of snow algae in Arctic habitats. Front. Microbiol. 2012, 3, 380. [CrossRef]

64. Procházková, L.; Remias, D.; Řezanka, T.; Nedbalová, L. Ecophysiology of Chloromonas hindakii sp. nov. (Chlorophyceae), causing orange snow blooms at different light conditions. Microorganisms 2019, 7, 434. [CrossRef] [PubMed]

65. Lang, I.; Hodač, L.; Friedl, T.; Feussner, I. Fatty acid profiles and their distribution patterns in microalgae: A comprehensive analysis of more than 2000 strains from the SAG culture collection. BMC Plant Biol. 2011, 11, 124. [CrossRef]

66. Lutz, S.; Anesio, A.M.; Raiswell, R.; Edwards, A.; Newton, R.J.; Gill, F.; Benning, L.G. The biogeography of red snow microbiomes and their role in melting arctic glaciers. Nat. Commun. 2016, 7, 11968. [CrossRef] [PubMed]

67. Procházková, L.; Remias, D.; Rezanka, T.; Nedbalová, L. Chloromonas nivalis subsp. tatrae, subsp. nov. (Chlamydomonadales, Chlorophyta): Re-examination of a snow alga from the High Tatra Mountains (Slovakia). Fottea 2018, 18, 1-18. [CrossRef] [PubMed]

68. Osipova, S.; Dudareva, L.; Bondarenko, N.; Nasarova, A.; Sokolova, N.; Obolkina, L.; Glyzina, O.; Timoshkin, O. Temporal variation in fatty acid composition of Ulothrix zonata (Chlorophyta) from ice and benthic communities of Lake Baikal. Phycologia 2009, 48, 130-135. [CrossRef] 
69. Abe, K.; Hattori, H.; Hirano, M. Accumulation and antioxidant activity of secondary carotenoids in the aerial microalga Coelastrella striolata var. multistriata. Food Chem. 2007, 100, 656-661. [CrossRef]

70. Da Silva, M.E.T.; Martins, M.A.; de Oliveira Leite, M.; Milião, G.L.; dos Reis Coimbra, J.S. Microalga Scenedesmus obliquus: Extraction of bioactive compounds and antioxidant activity. Rev. Cienc. Agron. 2021, 52, e20196848. [CrossRef]

71. Da Silva, M.E.T.; de Paula Correa, K.; Martins, M.A.; da Matta, S.L.P.; Martino, H.S.D.; dos Reis Coimbra, J.S. Food safety, hypolipidemic and hypoglycemic activities, and in vivo protein quality of microalga Scenedesmus obliquus in Wistar rats. J. Funct. Foods 2020, 65, 103711. [CrossRef]

72. Rocha, D.N.; Martins, M.A.; Soares, J.; Vaz, M.G.M.V.; de Oliveira Leite, M.; Covell, L.; Mendes, L.B.B. Combination of trace elements and salt stress in different cultivation modes improves the lipid productivity of Scenedesmus spp. Bioresour. Technol. 2019, 289, 121644. [CrossRef]

73. Wiltshire, K.H.; Boersma, M.; Möller, A.; Buhtz, H. Extraction of pigments and fatty acids from the green alga Scenedesmus obliquus (Chlorophyceae). Aquatic Ecol. 2000, 34, 119-126. [CrossRef]

74. Sallal, A.K.; Nimer, N.A.; Radwan, S.S. Lipid and fatty acid composition of freshwater cyanobacteria. Microbiology 1990, 136, 2043-2048. [CrossRef]

75. Zepke, H.D.; Heinz, E.; Radunz, A.; Linscheid, M.; Pesch, R. Combination and positional distribution of fatty acids in lipids from blue-green algae. Arch. Microbiol. 1978, 119, 157-162. [CrossRef]

76. Thangavel, K.; Krishnan, P.R.; Nagaiah, S.; Kuppusamy, S.; Chinnasamy, S.; Rajadorai, J.S.; Olaganathan, G.N.; Dananjeyan, B. Growth and metabolic characteristics of oleaginous microalgal isolates from Nilgiri biosphere Reserve of India. BMC Microbiol. 2018, 18, 1. [CrossRef] [PubMed]

77. Yeesang, C.; Cheirsilp, B. Effect of nitrogen, salt, and iron content in the growth medium and light intensity on lipid production by microalgae isolated from freshwater sources in Thailand. Bioresour. Technol. 2011, 102, 3034-3040. [CrossRef] [PubMed]

78. Lee, S.; Lim, S.R.; Jeong, D.G.; Kim, J.H. Characterization of an oleaginous unicellular green microalga, Lobosphaera incisa (Reisigl, 1964) Strain K-1, isolated from a tidal flat in the Yellow Sea, Republic of Korea. Front. Microbiol. 2018, 9, 2159. [CrossRef] [PubMed]

79. Bigogno, C.; Khozin-Goldberg, I.; Cohen, Z. Accumulation of arachidonic acid-rich triacylglycerols in the microalga Parietochloris incisa (Trebuxiophyceae, Chlorophyta). Phytochemistry 2002, 60, 135-143. [CrossRef]

80. Bigogno, C.; Khozin-Goldberg, I.; Boussiba, S.; Vonshak, A.; Cohen, Z. Lipid and fatty acid composition of the green oleaginous alga Parietochloris incisa, the richest plant source of arachidonic acid. Phytochemistry 2002, 60, 497-503. [CrossRef]

81. Khozin-Goldberg, I.; Bigogno, C.; Shrestha, P.; Cohen, Z. Nitrogen starvation induces the accumulation of arachidonic acid in the freshwater green alga Parietochloris incisa (Trebuxiophyceae). J. Phycol. 2002, 38, 991-994. [CrossRef]

82. Abu-Ghosh, S.; Pal-Nath, D.; Markovitch, D.; Solovchenko, A.; Didi-Cohen, S.; Portugal, I.; Khozin-Goldberg, I.; Cohen, Z.; Boussiba, S. A novel source of dihomo- $\gamma$-linolenic acid: Possibilities and limitations of DGLA production in the high-density cultures of the $\Delta 5$ desaturase-mutant microalga Lobosphaera incisa. Eur. J. Lipid Sci. Technol. 2015, 117, 760-766. [CrossRef]

83. Takai, S.; Jin, D.; Kawashima, H.; Kimura, M.; Shiraishi-Tateishi, A.; Tanaka, T.; Kakutani, S.; Tanaka, K.; Kiso, Y.; Miyazaki, M. Anti-atherosclerotic effects of dihomo-gamma-linolenic acid in ApoE-deficient mice. J. Atheroscler. Thromb. 2009, 16, 480-489. [CrossRef]

84. Guil-Guerrero, J.; Belarbi, E.H.; Rebolloso-Fuentes, M. Eicosapentaenoic and arachidonic acids purification from the red microalga Porphyridium cruentum. Bioseparation 2000, 9, 299-306. [CrossRef] [PubMed]

85. Cohen, Z.; Vonshak, A.; Richmond, A. Effect of environmental conditions on fatty acid composition of the red alga Porphyridium cruentum: Correlation to growth rate. J. Phycol. 1988, 24, 328-332. [CrossRef]

86. Cohen, Z. The production potential of eicosapentaenoic and arachidonic acids by the red alga Porphyridium cruentum. J. Am. Oil Chem. Soc. 1990, 67, 916-920. [CrossRef]

87. Cohen, Z.; Cohen, S. Preparation of eicosapentaenoic acid concentrate from Porphyridium cruentum. J. Am. Oil Chem. Soc. 1991, 68, 16-19. [CrossRef]

88. Asgharpour, M.; Rodgers, B.; Hestekin, J.A. Eicosapentaenoic acid from Porphyridium cruentum: Increasing growth and productivity of microalgae for pharmaceutical products. Energies 2015, 8, 10487-10503. [CrossRef]

89. Cohen, Z.; Khozin-Goldberg, I.; Adlerstein, D.; Bigogno, C. The role of triacylglycerol as a reservoir of polyunsaturated fatty acids for the rapid production of chloroplastic lipids in certain microalgae. Biochem. Soc. Trans. 2002, 28, 740-743. [CrossRef]

90. Iwamoto, H.; Sato, S. Production of EPA by freshwater unicellular algae. J. Am. Oil. Chem. Soc. 1968, 71, 434.

91. Cohen, Z. Production potential of eicosapentaenoic acid by Monodus subterraneus. J. Am. Oil Chem. Soc. 1994, 71, 941-945. [CrossRef]

92. Khozin-Goldberg, I.; Didi-Cohen, S.; Cohen, Z. Biosynthesis of eicosapentaenoic acid (EPA) in the freshwater eustigmatophyte Monodus subterraneus (Eustigmatophyceae). J. Phycol. 2002, 38, 745-756. [CrossRef]

93. Lu, C.; Rao, K.; Hall, D.; Vonshak, A. Production of eicosapentaenoic acid (EPA) in Monodus subterraneus grown in a helical tubular photobioreactor as affected by cell density and light intensity. J. Appl. Phycol. 2001, 13, 517-522. [CrossRef]

94. Vazhappilly, R.; Chen, F. Eicosapentaenoic acid and docosahexaenoic acid production potential of microalgae and their heterotrophic growth. J. Am. Oil Chem. Soc. 1998, 75, 393-397. [CrossRef]

95. López, G.; Yate, C.; Ramos, F.A.; Cala, M.P.; Restrepo, S.; Baena, S. Production of polyunsaturated fatty acids and lipids from autotrophic, mixotrophic and heterotrophic cultivation of Galdieria sp. strain USBA-GBX-832. Sci. Rep. 2019, 9, 10791. [CrossRef] [PubMed] 
96. Graziani, G.; Schiavo, S.; Nicolai, M.A.; Buono, S.; Fogliano, V.; Pinto, G.; Pollio, A. Microalgae as human food: Chemical and nutritional characteristics of the thermo-acidophilic microalga Galdieria sulphuraria. Food Funct. 2013, 4, 144-152. [CrossRef] [PubMed]

97. Gross, W.; Oesterhelt, C.; Tischendorf, G.; Lederer, F. Characterization of a non-thermophilic strain of the red algal genus Galdieria isolated from Soos (Czech Republic). Eur. J. Phycol. 2002, 37, 477-482. [CrossRef]

98. Pollio, A.; Della Greca, M.; Monaco, P.; Pinto, G.; Previtera, L. Lipid composition of the acidophilic alga Dunaliella acidophila (Volvocales, Chlorophyta) I. Nonpolar lipids. Biochim. Biophys. Acta 1988, 963, 53-60. [CrossRef]

99. Hernandez, E.M. Pharmaceutical and cosmetic use of lipids. In Bailey's Industrial Oil and Fat Products; Wiley: Hoboken, NJ, USA, 2020; pp. 1-28. [CrossRef]

100. Rabasco Álvarez, A.M.; Gonzalez Rodriguez, M.L. Lipids in pharmaceutical and cosmetic preparations. Grasas Aceites 2000, 51, 74-96. [CrossRef]

101. Becker, E.W. Microalgae: Biotechnology and Microbiology; Cambridge University Press: Cambridge, UK, 1994.

102. Lee, R.E. Phycology, 4th ed.; Cambridge University Press: New York, NY, USA, 2008.

103. Sartori, S.K.; Diaz, M.A.N.; Diaz-Muñoz, G. Lactones: Classification, synthesis, biological activities, and industrial applications. Tetrahedron 2021, 84, 132001. [CrossRef]

104. Kim, Y.; Sengupta, S.; Sim, T. Natural and synthetic lactones possessing antitumor activities. Int. J. Mol. Sci. 2021, 22, 1052. [CrossRef]

105. Ferraz, H.M.C.; Bombonato, F.I.; Sano, M.K.; Longo, L.S. Natural occurrence, biological activities and synthesis of eight-, nine-, and eleven membered ring lactones. Quim. Nova 2008, 31, 885-900. [CrossRef]

106. Gutierrez, R.M.P.; Anaya Sosa, I.; Victoria, C.Y.T.; Flores, J.M.M. Sesquiterpene lactones: Antispasmodic principles of the freshwater algae Hydrodictyon reticulatum. Med. Chem. Res. 2012, 21, 1023-1029. [CrossRef]

107. Proteau, P.J.; Rossi, J.V.; Gerwick, W.H. Absolute stereochemistry of neohalicholactone from the brown alga Laminaria sinclairii. J. Nat. Prod. 1994, 57, 1717-1719. [CrossRef]

108. Barbosa, M.; Valentão, P.; Andrade, P.B. Biologically active oxylipins from enzymatic and nonenzymatic routes in macroalgae. Mar. Drugs 2016, 14, 23. [CrossRef]

109. Andreou, A.; Brodhun, F.; Feussner, I. Biosynthesis of oxylipins in non-mammals. Prog. Lipid Res. 2009, 48, 148-170. [CrossRef] [PubMed]

110. Cutignano, A.; Lamari, N.; d'ippolito, G.; Manzo, E.; Cimino, G.; Fontana, A. Lipoxygenase products in marine diatoms: A concise analytical method to explore the functional potential of oxylipins. J. Phycol. 2011, 47, 233-243. [CrossRef] [PubMed]

111. Cardellina, J.H.; Moore, R.E. Malyngic acid, a new fatty acid from Lyngbya majuscula. Tetrahedron 1980, 36, 993-996. [CrossRef]

112. De los Reyes, C.; Ávila-Román, J.; Ortega, M.J.; de la Jara, A.; García-Mauriño, S.; Motilva, V.; Zubía, E. Oxylipins from the microalgae Chlamydomonas debaryana and Nannochloropsis gaditana and their activity as TNF- $\alpha$ inhibitors. Phytochemistry 2014, 102, 152-161. [CrossRef] [PubMed]

113. Murakami, N.; Shirahashi, H.; Nagatsu, A.; Sakakibara, J. Two unsaturated 9R-hydroxy fatty acids from the cyanobacterium Anabaena flos-aquae f. flos-aquae. Lipids 1992, 27, 776-778. [CrossRef]

114. Mundt, S.; Kreitlow, S.; Jansen, R. Fatty acids with antibacterial activity from the cyanobacterium Oscillatoria redekei HUB 051. J. Appl. Phycol. 2003, 15, 263-267. [CrossRef]

115. Lang, I.; Feussner, I. Oxylipin formation in Nostoc punctiforme (PCC73102). Phytochemistry 2007, 68, 1120-1127. [CrossRef]

116. Lang, I.; Göbel, C.; Porzel, A.; Heilmann, I.; Feussner, I. A lipoxygenase with linoleate diol synthase activity from Nostoc sp. PCC 7120. Biochem. J. 2008, 410, 347-357. [CrossRef]

117. Graf, W.; Baier, W. Hygienic and microbiological influences exerted on natural water biotopes by algae and the growth of water plants. 1. Communication: Antibacterial properties of three water algae (Hydrodictyon reticulatum, Chlorella vulgaris, Aphanothece nidulans) in vitro. Zent. Bakteriol. Mikrobiol. Hyg. B 1981, 174, 421-442.

118. Volkman, J.K.; Barrett, S.M.; Dunstan, G.A.; Jeffrey, S.W. C30-C32 alkyl diols and unsaturated alcohols in microalgae of the class Eustigmatophyceae. Org. Geochem. 1992, 18, 131-138. Available online: http://hdl.handle.net/102.100.100/249089?index=1 (accessed on 25 November 2021). [CrossRef]

119. Sorigué, D.; Légeret, B.; Cuiné, S.; Morales, P.; Mirabella, B.; Guédeney, G.; Li-Beisson, Y.; Jetter, R.; Peltier, G.; Beisson, F. Microalgae synthesize hydrocarbons from long-chain fatty acids via a light-dependent pathway. Plant Physiol. 2016, 171, 2393-2405. [CrossRef] [PubMed]

120. Coates, R.C.; Podell, S.; Korobeynikov, A.; Lapidus, A.; Pevzner, P.; Sherman, D.H.; Allen, E.E.; Gerwick, L.; Gerwick, W.H. Characterization of cyanobacterial hydrocarbon composition and distribution of biosynthetic pathways. PLoS ONE 2014, 9, e85140. [CrossRef]

121. Kawamura, K.; Nishikawa, S.; Hirano, K.; Ardianor, A.; Nugroho, R.A.; Okada, S. Large-scale screening of natural genetic resource in the hydrocarbon-producing microalga Botrycoccus braunii identified novel fast-growing strains. Sci. Rep. 2021, 11, 7368. [CrossRef] [PubMed]

122. Satoh, A.; Kato, M.; Yamato, K.; Ishibashi, M.; Sekiguchi, H.; Kurano, N.; Miyachi, S. Characterization of the lipid accumulation in a new microalgal species, Pseudochoricystis ellipsoidea (Trebouxiophyceae). J. Jpn. Inst. Energy 2010, 89, 909-913. [CrossRef]

123. Abedin, M.R.; Barua, S. Isolation and purification of glycoglycerolipids to induce apoptosis in breast cancer cells. Sci. Rep. 2021, 11, 1298. [CrossRef] [PubMed] 
124. Murakami, H.; Nobusawa, T.; Hori, K.; Shimojima, M.; Ohta, H. Betaine lipid is crucial for adapting to low temperature and phosphate deficiency in nannochloropsis. Plant Physiol. 2018, 177, 181-193. [CrossRef] [PubMed]

125. Dembitsky, V.M. Betaine ether-linked glycerolipids: Chemistry and biology. Prog. Lipid Res. 1996, 35, 1-51. [CrossRef]

126. Cañavate, J.P.; Armada, I.; Ríos, J.L.; Hachero-Cruzado, I. Exploring occurrence and molecular diversity of betaine lipids across taxonomy of marine microalgae. Phytochemistry 2016, 124, 68-78. [CrossRef]

127. Khozin-Goldberg, I.; Cohen, Z. The effect of phosphate starvation on the lipid and fatty acid composition of the fresh water eustigmatophyte Monodus subterraneus. Phytochemistry 2006, 67, 696-701. [CrossRef]

128. Vítová, M.; Goecke, F.; Sigler, K.; Řezanka, T. Lipidomic analysis of the extremophilic red alga Galdieria sulphuraria in response to changes in pH. Algal Res. 2016, 13, 218-226. [CrossRef]

129. Kato, M.; Sakai, M.; Adachi, K.; Ikemoto, H.; Sano, H. Distribution of betaine lipids in marine algae. Phytochemistry 1996, 42, 1341-1345. [CrossRef]

130. Riekhof, W.R.; Sears, B.B.; Benning, C. Annotation of genes involved in glycerolipid biosynthesis in Chlamydomonas reinhardtii: Discovery of the betaine lipid synthase BTA1 ${ }_{\mathrm{Cr}}$. Eukaryot. Cell 2005, 4, 242-252. [CrossRef] [PubMed]

131. Giroud, C.; Gerber, A.; Eichenberger, W. Lipids of Chlamydomonas reinhardtii. Analysis of molecular species and intracellular site(s) of biosynthesis. Plant Cell Physiol. 1988, 29, 587-595. [CrossRef]

132. Kumari, A.; Das, P.; Parida, A.K.; Agarwal, P.K. Proteomics, metabolomics, and ionomics perspectives of salinity tolerance in halophytes. Front. Plant Sci. 2015, 6, 537. [CrossRef]

133. Peretó, J.; López-García, P.; Moreira, D. Ancestral lipid biosynthesis and early membrane evolution. Trends Biochem. Sci. 2004, 29, 469-477. [CrossRef] [PubMed]

134. Khozin-Goldberg, I. Lipid Metabolism in Microalgae. In The Physiology of Microalgae. Developments in Applied Phycology; Borowitzka, M.A., Beardall, J., Raven, J.A., Eds.; Springer: Cham, Switzerland, 2016; Volume 6, pp. 413-484.

135. Li, J.; He, Y.; Anankanbil, S.; Guo, Z. Phospholipid-based surfactants. In Biobased Surfactants. Synthesis, Properties, and Applications, 2nd ed.; Hayes, D.G., Solaiman, D.K.Y., Ashby, R.D., Eds.; Academic Press: London, UK; AOCS Press: Champaign, IL, USA, 2019; pp. 243-286.

136. Sharma, K.; Shi, Y. The yins and yangs of ceramide. Cell Res. 1999, 9, 1-10. [CrossRef] [PubMed]

137. Stonik, V.A.; Stonik, I.V. Sterol and sphingoid glycoconjugates from microalgae. Mar. Drugs 2018, 16, 514. [CrossRef]

138. Miazek, K.; Lebecque, S.; Hamaidia, M.; Paul, A.; Danthine, S.; Willems, L.; Frederich, M.; De Pauw, E.; Deleu, M.; Richel, A.; et al. Sphingolipids: Promising lipid-class molecules with potential applications for industry. A review. Biotechnol. Agron. Soc. Environ. 2016, 20, 321-336. [CrossRef]

139. Elkhayat, E.S.; Mohamed, G.A.; Ibrahim, S.R.M. Activity and structure elucidation of ceramides. Curr. Bioact. Compd. 2012, 8 , 370-409. [CrossRef]

140. Heung, L.J.; Luberto, C.; Del Poeta, M. Role of sphingolipids in microbial pathogenesis. Infect. Immun. 2006, 74, 28-39. [CrossRef] [PubMed]

141. Schneider-Schaulies, J.; Schneider-Schaulies, S. Viral infections and sphingolipids. Handb. Exp. Pharmacol. 2013, 216, 321-340. [CrossRef]

142. Sharma, M.; Garg, H.; Chandra, K. Erythro-sphinga-4,8-dienine-N-palmitate: An antiviral agent from the green alga Ulva fasciata. Bot. Mar. 1996, 39, 213-216. [CrossRef]

143. Park, K.; Lee, S.; Lee, Y.M. Sphingolipids and antimicrobial peptides: Function and roles in atopic dermatitis. Biomol. Ther. 2013, 21, 251-257. [CrossRef]

144. Bano, S.; Uddin, S.; Ahmed, V.U. Marine natural products. Part XV. An acetylated derivative of a new N-acylsphingosine from red alga Halymenia porphyroides. Planta Med. 1990, 56, 233-234. [CrossRef]

145. Garg, H.S.; Sharma, M.; Bhakuni, D.S.; Pramanik, B.N.; Bose, A.K. An antiviral sphingosine derivative from the green alga Ulva fasciata. Tetrahedron Lett. 1992, 33, 1641-1644. [CrossRef]

146. Bibel, D.J.; Aly, R.; Shinefield, H.R. Antimicrobial activity of sphingosines. J. Investig. Dermatol. 1992, 98, 269-273. [CrossRef]

147. Bibel, D.J.; Aly, R.; Shah, S.; Shinefield, H.R. Sphingosines: Antimicrobial barriers of the skin. Acta Derm. Venereol. 1993, 73, 407-411. [CrossRef] [PubMed]

148. Li, Y.; Lou, Y.; Mu, T.; Ke, A.; Ran, Z.; Xu, J.; Chen, J.; Zhou, C.; Yan, X.; Xu, Q.; et al. Sphingolipids in marine microalgae: Development and application of a mass spectrometric method for global structural characterization of ceramides and glycosphingolipids in three major phyla. Anal. Chim. Acta 2017, 986, 82-94. [CrossRef]

149. Liu, M.; Li, X.; Chen, X.-Y.; Xue, F.; Zheng, J. Topical application of a linoleic acid-ceramide containing moisturizer exhibit therapeutic and preventive benefits for psoriasis vulgaris: A randomized controlled trial. Dermatol. Ther. 2015, 28 , 373-382. [CrossRef]

150. Imokawa, G.; Abe, A.; Jin, K.; Higaki, Y.; Kawashima, M.; Hidano, A. Decreased level of ceramides in stratum corneum of atopic dermatitis: An etiologic factor in atopic dry skin? J. Investig. Dermatol. 1991, 96, 523-526. [CrossRef]

151. Zhang, N.; Kohama, K.; Miyagawa, M.; Mansho, M.; Sugimoto, R.; Nakashima, A.; Suzuki, K.; Kitagaki, H. Identification of monohexosylceramides from Euglena gracilis by electrospray ionization mass spectrometry. Nat. Prod. Commun. 2020, 15, 1-4. [CrossRef]

152. Tsuji, K.; Mitsutake, S.; Ishikawa, J.; Takagi, Y.; Akiyama, M.; Shimizu, H.; Tomiyama, T.; Igarashi, Y. Dietary glucosylceramide improves skin barrier function in hairless mice. J. Dermatol. Sci. 2006, 44, 101-107. [CrossRef] 
153. Ideta, R.; Sakuta, T.; Nakano, Y.; Uchiyama, T. Orally administered glucosylceramide improves the skin barrier function by upregulating genes associated with the tight junction and cornified envelope formation. Biosci. Biotechnol. Biochem. 2011, 75, 1516-1523. [CrossRef] [PubMed]

154. Uchiyama, T.; Nakano, Y.; Ueda, O.; Mori, H.; Nakashima, M.; Noda, A.; Ishizaki, C.; Mizoguchi, M. Oral intake of glucosylceramide improves relatively higher level of transepidermal water loss in mice and healthy human subjects. J. Health Sci. 2008, 54, 559-566. [CrossRef]

155. Shimada, E.; Aida, K.; Sugawara, T.; Hirata, T. Inhibitory effect of topical maize glucosylceramide on skin photoaging in UV airradiated hairless mice. J. Oleo Sci. 2011, 60, 321-325. [CrossRef] [PubMed]

156. Inafuku, M.; Li, C.; Kanda, Y.; Kawamura, T.; Takeda, K.; Oku, H.; Watanabe, H. Beta-glucosylceramide administration (i.p.) activates natural killer $\mathrm{T}$ cells in vivo and prevents tumor metastasis in mice. Lipids 2012, 47, 581-591. [CrossRef] [PubMed]

157. Sugawara, T.; Aida, K.; Duan, J.; Tomonaga, N.; Manabe, Y.; Hirata, T. Analysis of chemical structures of glucosylceramides from rice and other foodstuffs. J. Nutr. Sci. Vitaminol. 2019, 65, S228-S230. [CrossRef]

158. Miyagawa, M.; Fujikawa, A.; Nagadome, M.; Kohama, K.; Ogami, T.; Kitamura, S.; Kitagaki, H. Glycosylceramides purified from the Japanese traditional non-pathogenic fungus Aspergillus and Koji increase the expression of genes involved in tight junctions and ceramide delivery in normal human epidermal keratinocytes. Fermentation 2019, 5, 43. [CrossRef]

159. Tanaka, I.; Matsuoka, S.; Murata, M.; Tachibana, K. A new ceramide with a novel branched-chain fatty acid isolated from the epiphytic dinoflagellate Coolia monotis. J. Nat. Prod. 1998, 61, 685-688. [CrossRef] [PubMed]

160. Khotimchenko, S.V.; Vas'kovskii, V.E. An inositol-containing sphingolipid from red algae Gracilaria verrucosa. Russ. J. Bioorg. Chem. 2004, 30, 168-171. [CrossRef] [PubMed]

161. Arakaki, A.; Iwama, D.; Liang, Y.; Murakami, N.; Ishikura, M.; Tanaka, T.; Matsunaga, T. Glycosylceramides from marine green microalga Tetraselmis sp. Phytochemistry 2013, 85, 107-114. [CrossRef] [PubMed]

162. Youssef, D.T.A.; Ibrahim, S.R.M.; Shaala, L.A.; Mohamed, G.A.; Banjar, Z.M. New Cerebroside and Nucleoside Derivatives from a Red Sea Strain of the Marine Cyanobacterium Moorea producens. Molecules 2016, 21, 324. [CrossRef] [PubMed]

163. Ganfield, M.C.W. Isolation and Characterization of Sphingolipid from Ochromonas danica. Ph.D. Thesis, Iowa State University, Ames, IA, USA, 1970. Retrospective Theses and Dissertations. p. 4308. Available online: https://lib.dr.iastate.edu/rtd/4308 (accessed on 7 November 2021).

164. Mahendran, M.; Somasundaram, S.; Thomson, T.H. A revised structure for caulerpicin from Caulerpa racemosa. Phytochemistry 1979, 18, 1885-1886. [CrossRef]

165. Zhao, F.; Xu, J.; Chen, J.; Yan, X.; Zhou, C.; Li, S.; Xu, X.; Ye, F. Structural elucidation of two types of novel glycosphingolipids in three strains of Skeletonema by liquid chromatography coupled with mass spectrometry. Rapid Commun. Mass Spectrom. 2013, 27, 1535-1547. [CrossRef] [PubMed]

166. Romsdahl, T.B. Characterization of Volvocine Sphingolipid Metabolism; ETD Collection for University of Nebraska-Lincoln; AAI10690895. 2017. Available online: https:/ /digitalcommons.unl.edu/dissertations/AAI10690895 (accessed on 25 November 2021).

167. Xu, S.-H.; Cen, Y.-Z.; Zeng, L.-M. Sertularamide from the alga Caulerpa sertularioides. Chin. Chem. Lett. 1997, 8, 419-420. [CrossRef]

168. Lo, J.-M.; Wang, W.-L.; Chiang, Y.-M.; Chen, C.-M. Ceramides from the Taiwan red alga Ceratodictyon spongiosum and symbiotic sponge Sigmadocia symbiotica. J. Chin. Chem. Soc. 2001, 48, 821-826. [CrossRef]

169. Ishida, R.; Shirahama, H.; Matsumoto, T. A new glycosphingolipids from the red alga Corallina pilulifera. Chem. Lett. 1993, 22, 9-12. [CrossRef]

170. Rao, C.B.; Satyanarayana, C. A new sphingosine derivative from the red alga Halymenia durivilliae of Andaman and Nicobar Islands. Indian J.Chem. 1994, 33B, 97-98.

171. Muralidhar, P.; Radhika, P.; Krishna, N.; Rao, D.V.; Rao, C.B. Sphingolipids from marine organisms: A Review. Nat. Prod. Sci. 2003, 9, 117-142.

172. Volkman, J.K. Sterols in microrganisms. Appl. Microbiol. Biotechnol. 2003, 60, 495-506. [CrossRef]

173. Fagundes, M.B.; Wagner, R. Sterols biosynthesis in algae. In Bioactive Compounds. Biosynthesis, Characterization and Applications; Zepka, L.Q., Ed.; IntechOpen: London, UK, 2021. [CrossRef]

174. Porsbring, T.; Blanck, H.; Tjellström, H.; Backhaus, T. Toxicity of the pharmaceutical clotrimazole to marine microalgal communities. Aquat. Toxicol. 2009, 91, 203-211. [CrossRef]

175. Voshall, A.; Christie, N.T.M.; Rose, S.L.; Khasin, M.; Van Etten, J.L.; Markham, J.E.; Riekhof, W.R.; Nickerson, K.W. Sterol Biosynthesis in four green algae: A bioinformatic analysis of the ergosterol versus phytosterol decision point. J. Phycol. 2021, 57, 1199-2111. [CrossRef] [PubMed]

176. Blanc, M.; Hsieh, W.Y.; Robertson, K.A.; Watterson, S.; Shui, G.; Lacaze, P.; Khondoker, M.; Dickinson, P.; Sing, G.; RodríguezMartín, S.; et al. Host defense against viral infection involves interferon mediated down-regulation of sterol biosynthesis. PLoS Biol. 2011, 9, e1000598. [CrossRef]

177. Luo, X.; Su, P.; Zhang, W. Advances in microalgae-derived phytosterols for functional food and pharmaceutical applications. Mar. Drugs 2015, 13, 4231-4254. [CrossRef] [PubMed]

178. Le Goff, M.; Le Ferrec, E.; Mayer, C.; Mimouni, V.; Lagadic-Gossmann, D.; Schoefs, B.; Ulmann, L. Microalgal carotenoids and phytosterols regulate biochemical mechanisms involved in human health and disease prevention. Biochimie 2019, 167, 106-118 [CrossRef] [PubMed] 
179. Volkman, J.K. Sterols in microalgae. In The Physiology of Microalgae. Developments in Applied Phycology; Borowitzka, M.A., Beardall, J., Raven, J.A., Eds.; Springer: Cham, Switzerland, 2016; Volume 6, pp. 485-505.

180. Martin-Creuzburg, D.; Merkel, P. Sterols of freshwater microalgae: Potential implications for zooplankton nutrition. J. Plankton Res. 2016, 38, 865-877. [CrossRef]

181. Moreau, R.A.; Whitaker, B.D.; Hicks, K.B. Phytosterols, phytostanols, and their conjugates in foods: Structural diversity, quantitative analysis, and health-promoting uses. Prog. Lipid Res. 2002, 41, 457-500. [CrossRef]

182. Iwata, I.; Nakata, H.; Mizushima, M.; Sakurai, Y. Lipids of algae. Part I. The components of unsaponifiable matter of the algae Scenedesmus. Agric. Biol. Chem. 1961, 25, 319-325. [CrossRef]

183. Akihisa, T.; Hori, T.; Suzuki, H.; Sakoh, T.; Yokota, T.; Tamura, T. $24 \beta$-Methyl-5 $\alpha$-cholest-9(11)-en-3 $\beta$-ol, two $24 \beta$-alkyl- $\Delta 5,7,9(11)$ sterols and other $24 \beta$-alkylsterols from Chlorella vulgaris. Phytochemistry 1992, 31, 1769-1772. [CrossRef]

184. Rezanka, T.; Vyhnalek, O.; Podojil, M. Identification of sterols and alcohols produced by green algae of the genera Chlorella and Scenedesmus by means of gas chromatography-mass spectrometry. Folia Microbiol. 1986, 31, 44-49. [CrossRef]

185. Rampen, S.W.; Abbas, B.A.; Schouten, S.; Damsté, J.S. A comprehensive study of sterols in marine diatoms (Bacillariophyta): Implications for their use as tracers for diatom productivity. Limnol. Oceanogr. 2010, 55, 91-105. [CrossRef]

186. De Souza, N.J.; Nes, W.R. Sterols: Isolation from a bluegreen alga. Science 1968, 162, 363. [CrossRef] [PubMed]

187. Konlhase, M.; Pohl, P. Saturated and unsaturated sterols of nitrogen-fixing blue-green algae (cyanobacteria). Phytochemistry 1988, 27, 1735-1740. [CrossRef]

188. Paoletti, C.; Pushparaj, B.; Florenzano, G.; Capella, P.; Lercker, G. Unsaponifiable matter of green and blue-green algal lipids as a factor of biochemical differentiation of their biomasses: II. Terpenic alcohol and sterol fractions. Lipids 1976, 11, $266-271$. [CrossRef]

189. Fagundes, M.B.; Falk, R.B.; Facchi, M.M.X.; Vendruscolo, R.G.; Maroneze, M.M.; Zepka, L.Q.; Wagner, R. Insights in cyanobacteria lipidomics: A sterols characterization from Phormidium autumnale biomass in heterotrophic cultivation. Food Res. Int. 2019, 119, 777-784. [CrossRef]

190. Rasmussen, H.E.; Blobaum, K.R.; Park, Y.-K.; Ehlers, S.J.; Lu, F.; Lee, J.-Y. Lipid extract of Nostoc commune var. sphaeroides Kützing, a blue-green alga, inhibits the activation of sterol regulatory element binding proteins in HepG2 Cells. J. Nutr. 2008, 138, 476-481. [CrossRef]

191. Řezanka, T.; Dembitsky, V.M.; Go, J.V. Sterol compositions of the filamentous nitrogen-fixing terrestrial cyanobacterium Scytonema sp. Folia Microbiol. 2003, 48, 357-360. [CrossRef]

192. Seckbach, J.; Ikan, R.; Ringelberg, D.; White, D. Sterols and phylogeny of the acidophilic hot springs algae Cyanidium caldarium and Galdieria sulphuraria. Phytochemistry 1993, 34, 1345-1349. [CrossRef]

193. Gross, W.; Küver, J.; Tischendorf, G.; Bouchaala, N.; Büsch, W. Cryptoendolithic growth of the red alga Galdieria sulphuraria in volcanic areas. Eur. J. Phycol. 1998, 33, 25-31. [CrossRef]

194. Liu, L.; Sanchez-Arcos, C.; Pohnert, G.; Wei, D. Untargeted metabolomics unveil changes in autotrophic and mixotrophic Galdieria sulphuraria exposed to high-light intensity. Int. J. Mol. Sci. 2021, 22, 1247. [CrossRef] [PubMed]

195. Yasukawa, K.; Akihisa, T.; Kanno, H.; Kaminaga, T.; Izumida, M.; Sakoh, T.; Tamura, T.; Takido, M. Inhibitory effects of sterols isolated from Chlorella vulgaris on 12-O-tetradecanoylphorbol-13-acetate-Induced inflammation and tumor promotion in mouse skin. Biol. Pharm. Bull. 1996, 19, 573-576. [CrossRef] [PubMed]

196. Honda, M.; Kageyama, H.; Hibino, T.; Ichihashi, K.; Takada, W.; Goto, M. Isomerization of commercially important carotenoids (lycopene, $\beta$-carotene, and astaxanthin) by natural catalysts: Isothiocyanates and polysulfides. J. Agric. Food Chem. 2020, 68, 3228-3237. [CrossRef]

197. Gupta, A.K.; Seth, K.; Maheshwari, K.; Baroliya, P.K.; Meena, M.; Kumar, A.; Vinayak, V.; Harish. Biosynthesis and extraction of high-value carotenoid from algae. Front. Biosci. Landmark 2021, 26, 171-190. [CrossRef]

198. Alparslan, L.; Sekeroglu, N.; Kijjoa, A. The potential of marine resources in cosmetics. Curr. Perspect. Med. Aromat. Plants 2018, 2 , 53-66. Available online: https:/ / dergipark.org.tr/en/download/article-file/613473 (accessed on 5 November 2021). [CrossRef]

199. Stoyneva-Gärtner, M.; Stoykova, P.; Uzunov, B.; Dincheva, I.; Atanassov, I.; Draganova, P.; Borisova, C.; Gärtner, G. Carotenoids in five aeroterrestrial strains from Vischeria/Eustigmatos group: Updating the pigment patterns of Eustigmatophyceae. Biotechnol. Biotechnol. Equip. 2019, 33, 250-267. [CrossRef]

200. Ambati, R.R.; Gogisetty, D.; Aswathanarayana, R.G.; Ravi, S.; Bikkina, P.N.; Bo, L.; Yuepeng, S. Industrial potential of carotenoid pigments from microalgae: Current trends and future prospects. Crit. Rev. Food Sci. Nutr. 2019, 59, 1880-1902. [CrossRef] [PubMed]

201. Novoveská, L.; Ross, M.E.; Stanley, M.S.; Pradelles, R.; Wasiolek, V.; Sassi, J.F. Microalgal carotenoids: A review of production, current markets, regulations, and future direction. Mar. Drugs 2019, 17, 640. [CrossRef]

202. Sathasivam, R.; Ki, J.S. A review of the biological activities of microalgal carotenoids and their potential use in healthcare and cosmetic industries. Mar. Drugs 2018, 16, 26. [CrossRef]

203. Griffiths, K.; Aggarwal, B.; Singh, R.; Buttar, H.; Wilson, D.; De Meester, F. Food antioxidants and their anti-inflammatory properties: A potential role in cardiovascular diseases and cancer prevention. Diseases 2016, 4, 28. [CrossRef] [PubMed]

204. Cheng, S.-H.; Khoo, H.E.; Kong, K.W.; Prasad, K.N.; Galanakis, C.M. 8-Extraction of carotenoids and applications. In Carotenoids: Properties, Processing and Applications; Galanakis, C.M., Ed.; Academic Press: Oxford, UK, 2020; pp. 259-288. [CrossRef]

205. Bhosale, P.; Bernstein, P.S. Microbial xanthophylls. Appl. Microbiol. Biotechnol. 2005, 68, 445-455. [CrossRef] [PubMed] 
206. Suganuma, K.; Nakajima, H.; Ohtsuki, M.; Imokawa, G. Astaxanthin attenuates the UVA-induced up-regulation of matrixmetalloproteinase-1 and skin fibroblast elastase in human dermal fibroblasts. J. Dermatol. Sci. 2010, 58, 136-142. [CrossRef]

207. Mourelle, M.; Gómez, C.; Legido, J. The potential use of marine microalgae and cyanobacteria in cosmetics and thalassotherapy. Cosmetics 2017, 4, 46. [CrossRef]

208. Dixon, C.; Wilken, L.R. Green microalgae biomolecule separations and recovery. Bioresour. Bioprocess. 2018, 5, 14. [CrossRef]

209. Leon, R.; Martin, M.; Vigara, J.; Vilchez, C.; Vega, J.M. Microalgae mediated photoproduction of b-carotene in aqueous organic two-phase systems. Biomol. Eng. 2003, 20, 177-182. [CrossRef]

210. Gouveia, L.; Batista, A.P.; Sousa, I.; Raymundo, A.; Bandarra, N.M. Microalgae in novel food products. In Food Chemistry Research Developments; Papadopoulos, K.N., Ed.; Nova Science Publishers, Inc.: New York, NY, USA, 2008; pp. 75-111.

211. Ranga Rao, A.; Sindhuja, H.N.; Dharmesh, S.M.; Sankar, K.U.; Sarada, R.; Ravishankar, G.A. Effective inhibition of skin cancer, tyrosinase, and antioxidative properties by astaxanthin and astaxanthin esters from the green alga Haematococcus pluvialis. J. Agric. Food Chem. 2013, 61, 3842-3851. [CrossRef]

212. Kamath, B.S.; Srikanta, B.M.; Dharmesh, S.M.; Sarada, R.; Ravishankar, G.A. Ulcer preventive and antioxidative properties of astaxanthin from Haematococcus pluvialis. Eur. J. Pharmacol. 2008, 590, 387-395. [CrossRef] [PubMed]

213. Kim, Y.J.; Kim, Y.A.; Yokozawa, T. Protection against oxidative stress, inflammation, and apoptosis of high glucose- exposed proximal tubular epithelial cells by astaxanthin. J. Agric. Food Chem. 2009, 57, 8793-8797. [CrossRef] [PubMed]

214. Jyonouchi, H.; Sun, S.; Iijima, K.; Gross, M.D. Antitumor activity of astaxanthin and its mode of action. Nutr. Cancer 2000, 36, 59-65. [CrossRef] [PubMed]

215. Maoka, T.; Tokuda, H.; Suzuki, N.; Kato, H.; Etoh, H. Anti-oxidative, anti-tumor-promoting, and anti-carcinogenesis activities of nitroastaxanthin and nitrolutein, the reaction products of astaxanthin and lutein with peroxynitrite. Mar. Drugs 2012, 10, 1391-1399. [CrossRef]

216. Tominaga, K.; Hongo, N.; Karato, M.; Yamashita, E. Protective effects of astaxanthin against singlet oxygen induced damage in human dermal fibroblasts in vitro. FOOD Style 2009, 21, 84-86.

217. Tominaga, K.; Hongo, N.; Karato, M.; Yamashita, E. Cosmetic benefits of astaxanthin on humans subjects. Acta Biochim. Pol. 2012, 59, 43-47. [CrossRef]

218. Ambati, R.R.; Phang, S.-M.; Ravi, S.; Aswathanarayana, R.G. Astaxanthin: Sources, extraction, stability, biological activities and its commercial applications-A review. Mar. Drugs 2014, 12, 128-152. [CrossRef] [PubMed]

219. Yamashita, E. Suppression of post-UVB hyperpigmentation by topical astaxanthin from krill. Fragr. J. 1995, 14, 180-185.

220. Arakane, K. Superior skin protection via astaxanthin. Carotenoid Sci. 2002, 5, 21-24.

221. Seki, T.; Sueki, H.; Kono, H.; Suganuma, K.; Yamashita, E. Effects of astaxanthin from Haematococcus pluvialis on human skin-patch test; skin repeated application test; effect on wrinkle reduction. Fragr. J. 2001, 12, 98-103.

222. Yamashita, E. Cosmetic benefit of dietary supplements including astaxanthin and tocotrienol on human skin. FOOD Style 2002, 21, 112-117.

223. Yamashita, E. The effects of a dietary supplement containing astaxanthin on skin condition. Carotenoid Sci. 2006, 10, 91-95.

224. Hama, S.; Takahashi, K.; Inai, Y.; Shiota, K.; Sakamoto, R.; Yamada, A.; Tsuchiya, H.; Kanamura, K.; Yamashita, E.; Kogure, K. Protective effects of topical application of a poorly soluble antioxidant astaxanthin liposomal formulation on ultraviolet-induced skin damage. J. Pharm. Sci. 2012, 101, 2909-2916. [CrossRef]

225. Casal, C.; Cuaresma, M.; Vega, J.M.; Vilchez, C. Enhanced productivity of a lutein-enriched novel acidophile microalga grown on urea. Mar. Drugs 2011, 9, 29-42. [CrossRef]

226. Fernández-Sevilla, J.M.; Acién-Fernández, F.; Molina-Grima, E. Biotechnological production of lutein and its applications. Appl. Microbiol. Biotechnol. 2010, 86, 27-40. [CrossRef] [PubMed]

227. Bux, F. (Ed.) Biotechnological Applications of Microalgae Biodiesel and Value-Added Products; CRC Press: Boca Raton, FL, USA; Taylor \& Francis Group: Abingdon, UK, 2013.

228. Del Campo, J.A.; Rodríguez, H.; Moreno, J.; Varga, M.Á.; Rivas, J.; Guerrero, M.G. Carotenoid content of chlorophycean microalgae: Factors determining lutein accumulation in Muriellopsis sp. (Chlorophyta). J. Biotechnol. 2000, 76, 51-59. [CrossRef]

229. Del Campo, J.A.; Rodríguez, H.; Moreno, J.; Varga, M.Á.; Rivas, J.; Guerrero, M.G. Lutein production by Muriellopsis sp. in an outdoor tubular photobiorector. J. Biotechnol. 2001, 81, 289-295. [CrossRef]

230. Del Campo, J.A.; García-González, M.; Guerrero, M.G. Outdoor cultivation of microalgae for carotenoid production: Current state and perspectives. Appl. Microbiol. Biotechnol. 2007, 74, 1163-1174. [CrossRef]

231. Huss, V.A.; Ciniglia, C.; Cennamo, P.; Cozzolino, S.; Pinto, G.; Pollio, A. Phylogenetic relationships and taxonomic position of Chlorella-like isolates from low $\mathrm{pH}$ environments $(\mathrm{pH}<3.0)$. BMC Evol. Biol. 2002, 2, 13. [CrossRef]

232. Darienko, T.; Pröschold, T. Genetic variability and taxonomic revision of the genus Auxenochlorella (Shihira et Krauss) Kalina et Puncocharova (Trebouxiophyceae, Chlorophyta). J. Phycol. 2015, 51, 394-400. [CrossRef] [PubMed]

233. Gao, C.; Wang, Y.; Shen, Y.; Yan, D.; He, X.; Dai, J.; Wu, Q. Oil accumulation mechanisms of the oleaginous microalga Chlorella protothecoides revealed through its genome, transcriptomes, and proteomes. BMC Genomics 2014, 15, 582. [CrossRef] [PubMed]

234. Shi, X.-M.; Liu, H.-J.; Zhang, X.-W.; Chen, F. Production of biomass and lutein by Chlorella protothecoides at various glucose concentrations in heterotrophic cultures. Process Biochem. 1999, 34, 341-347. [CrossRef] 
235. Shi, X.M.; Chen, F. Production and rapid extraction of lutein and the other lipid-soluble pigments from Chlorella protothecoides grown under heterotrophic and mixotrophic conditions. Nahrung 1999, 43, 109-113. [CrossRef]

236. Shi, X.-M.; Chen, F.; Yuan, J.P.; Chen, H. Heterotrophic production of lutein by selected Chlorella strains. J. Appl. Phycol. 1997, 9 , 445-450. [CrossRef]

237. Heredia-Arroyo, T.; Wei, W.; Hu, B. Oil accumulation via heterotrophic/mixotrophic Chlorella protothecoides. Appl. Biochem. Biotechnol. 2010, 162, 1978-1995. [CrossRef] [PubMed]

238. Bar, E.; Rise, M.; Vishkautsan, M.; Arad, S. Pigment and structural changes in Chlorella zofingiensis upon light and nitrogen stress. J. Plant Physiol. 1995, 146, 527-534. [CrossRef]

239. Orosa, M.; Torres, E.; Fidalgo, P.; Abalde, J. Production and analysis of secondary carotenoids in green algae. J. Appl. Phycol. 2000, 12, 553-556. [CrossRef]

240. Pelah, D.; Sintov, A.; Cohen, E. The effect of salt stress on the production of canthaxanthin and astaxanthin by Chlorella zofingiensis grown under limited light intensity. World J. Microbiol. Biotechnol. 2004, 20, 483-486. [CrossRef]

241. Ip, P.F.; Chen, F. Production of astaxanthin by the green microalga Chlorella zofingiensis in the dark. Process Biochem. 2005, 40, 733-738. [CrossRef]

242. Ip, P.F.; Wong, K.-H.; Chen, F. Enhanced production of astaxanthin by the green microalga Chlorella zofingiensis in mixotrophic culture. Process Biochem. 2004, 39, 1761-1766. [CrossRef]

243. Del Campo, J.A.; Rodriguez, H.; Moreno, J.; Vargas, M.A.; Rivas, J.; Guerrero, M.G. Accumulation of astaxanthin and lutein in Chlorella zofingiensis (Chlorophyta). Appl. Microbiol. Biotechnol. 2004, 64, 848-854. [CrossRef] [PubMed]

244. Ye, Y.; Huang, J.-C. Defining the biosynthesis of ketocarotenoids in Chromochloris zofingiensis. Plant Divers. 2020, 42, 61-66. [CrossRef]

245. Liu, J.; Sun, Z.; Gerken, H.; Liu, Z.; Jiang, Y.; Chen, F. Chlorella zofingiensis as an alternative microalgal producer of astaxanthin: Biology and industrial potential. Mar. Drugs 2014, 12, 3487-3515. [CrossRef]

246. Mulders, K.J.M.; Weesepoel, Y.; Bodenes, P.; Lamers, P.P.; Vincken, J.-P.; Martens, D.E.; Gruppen, H.; Wijffels, R.H. Nitrogendepleted Chlorella zofingiensis produces astaxanthin, ketolutein and their fatty acid esters: A carotenoid metabolism study. J. Appl. Phycol. 2015, 27, 125-140. [CrossRef]

247. Orosa, M.; Valero, J.; Herrero, C. Comparison of the accumulation of astaxanthin in Haematococcus pluvialis and other green microalgae under N-starvation and high light conditions. Biotechnol. Lett. 2001, 23, 1079-1085. [CrossRef]

248. Qin, S.; Liu, G.-X.; Hu, Z.-Y. The accumulation and metabolism of astaxanthin in Scenedesmus obliquus (Chlorophyceae). Process Biochem. 2008, 43, 795-802. [CrossRef]

249. Koo, S.Y.; Cha, K.H.; Song, D.-G.; Chung, D.; Pan, C.-H. Optimization of pressurized liquid extraction of zeaxanthin from Chlorella ellipsoidea. J. Appl. Phycol. 2012, 24, 725-730. [CrossRef]

250. Theriault, R.J. Heterotrophic growth and production of xanthophylls by Chlorella pyrenoidosa. Appl. Microbiol. 1965, 13, 402-416. [CrossRef]

251. Singh, J.; Gu, S. Commercialization potential of microalgae for biofuels production. Renew. Sustain. Energy Rev. 2010, 14, 2596-2610. [CrossRef]

252. Wu, Z.; Wu, S.; Shi, X. Supercritical fluid extraction and determination of lutein in heterotrophically cultivated Chlorella pyrenoidosa. J. Food Process Eng. 2007, 30, 174-185. [CrossRef]

253. Chacón-Lee, T.L.; González-Mariño, G.E. Microalgae for "healthy” foods-possibilities and challenges. Compr. Rev. Food Sci. Food Saf. 2010, 9, 655-675. [CrossRef]

254. Cha, K.H.; Lee, H.J.; Koo, S.Y.; Song, D.-G.; Lee, D.-U.; Pan, C.-H. Optimization of pressurized liquid extraction of carotenoids and chlorophylls from Chlorella vulgaris. J. Agric. Food Chem. 2010, 58, 793-797. [CrossRef] [PubMed]

255. Deenu, A.; Naruenartwongsakul, S.; Kim, S.M. Optimization and economic evaluation of ultrasound extraction of lutein from Chlorella vulgaris. Biotechnol. Bioprocess Eng. 2013, 18, 1151-1162. [CrossRef]

256. Li, H.B.; Jiang, Y.; Chen, F. Isolation and purification of lutein from the microalga Chlorella vulgaris by extraction after saponification. J. Agric. Food Chem. 2002, 50, 1070-1072. [CrossRef] [PubMed]

257. Amaro, H.M.; Guedes, A.C.; Malcata, F.X. Advances and perspectives in using microalgae to produce biodiesel. Appl. Energy 2011, 88, 3402-3410. [CrossRef]

258. Chan, M.-C.; Ho, S.-H.; Lee, D.-J.; Chen, C.-Y.; Huang, C.-C.; Chang, J.-S. Characterization, extraction and purification of lutein produced by an indigenous microalga Scenedesmus obliquus CNW-N. Biochem. Eng. J. 2013, 78, 24-31. [CrossRef]

259. Ho, S.H.; Chan, M.C.; Liu, C.C.; Chen, C.Y.; Lee, W.L.; Lee, D.J.; Chang, J.S. Enhancing lutein productivity of an indigenous microalga Scenedesmus obliquus FSP-3 using light-related strategies. Bioresour. Technol. 2014, 152, 275-282. [CrossRef]

260. Higuera-Ciapara, I.; Felix-Valenzuela, L.; Goycoolea, F.M. Astaxanthin: A review of its chemistry and applications. Crit. Rev. Food Sci. Nutr. 2006, 46, 185-196. [CrossRef]

261. Zhang, D.H.; Lee, Y.K. Two-step process for ketocarotenoid production by a green alga, Chlorococcum sp. strain MA-1. Appl. Microbiol. Biotechnol. 2001, 55, 537-540. [CrossRef] [PubMed]

262. Zhang, D.H.; Lee, Y.K. Enhanced accumulation of secondary carotenoids in a mutant of the green alga, Chlorococcum sp. J. Appl. Phycol. 1997, 9, 459-463. [CrossRef]

263. Zhang, D.H.; Ng, M.L.; Phang, S.M. Composition and accumulation of secondary carotenoids in Chlorococcum sp. J. Appl. Phycol. 1997, 9, 147-155. [CrossRef] 
264. Li, H.B.; Chen, F. Preparative Isolation and purification of astaxanthin from the green microalga Chlorococcum sp. by high-speed counter-current chromatography. In Algae and Their Biotechnological Potential; Chen, F., Jiang, Y., Eds.; Springer: Dordrecht, The Netherlands, 2001. [CrossRef]

265. Masojídek, J.; Torzillo, G.; Kopecký, J.; Koblížek, M.; Nidiaci, L.; Komenda, J.; Lukavská, A.; Sacchi, A. Changes in chlorophyll fluorescence quenching and pigment composition in the green alga Chlorococcum sp. grown under nitrogen deficiency and salinity stress. J. Appl. Phycol. 2000, 12, 417-426. [CrossRef]

266. Leya, T.; Rahn, A.; Lütz, C.; Remias, D. Response of arctic snow and permafrost algae to high light and nitrogen stress by changes in pigment composition and applied aspects for biotechnology. FEMS Microbiol. Ecol. 2009, 67, 432-443. [CrossRef]

267. Kim, B.K.; Joo, H.; Lee, B.; Lee, D.-H.; Ahn, I.-Y.; Ha, S.-Y. Physiological characteristics and related biochemical parameters of snow algae from King George Island, Antarctica. Ocean Sci. J. 2018, 53, 621-630. [CrossRef]

268. Remias, D.; Lütz-Meindl, U.; Lütz, C. Photosynthesis, pigments and ultrastructure of the alpine snow alga Chlamydomonas nivalis. Eur. J. Phycol. 2005, 40, 259-268. [CrossRef]

269. Remias, D.; Lütz, C. Characterisation of esterified secondary carotenoids and of their isomers in green algae: A HPLC approach. Algol. Stud. 2005, 124, 85-94. [CrossRef]

270. Procházková, L.; Leya, T.; Kř́žková, H.; Nedbalová, L. Sanguina nivaloides and Sanguina aurantia gen. et spp. nov. (Chlorophyta): The taxonomy, phylogeny, biogeography and ecology of two newly recognised algae causing red and orange snow. FEMS Microbiol. Ecol. 2019, 95, fiz064. [CrossRef] [PubMed]

271. Remias, D.; Wastian, H.; Lütz, C.; Leya, T. Insight into the biology and phylogeny of Chloromonas polyptera (Chlorophyta), an alga causing orange snow in Maritime Antarctica. Antarct. Sci. 2013, 25, 648-656. [CrossRef]

272. Remias, D.; Pichrtová, M.; Pangratz, M.; Lütz, C.; Holzinger, A. Ecophysiology, secondary pigments and ultrastructure of Chlainomonas sp. (Chlorophyta) from the European Alps compared with Chlamydomonas nivalis forming red snow. FEMS Micorbiol. Ecol. 2016, 92, fiw030. [CrossRef] [PubMed]

273. Hoham, R.; Remias, D. Snow and glacial algae: A review. J. Phycol. 2020, 56, 264-282. [CrossRef]

274. Remias, D.; Albert, A.; Lütz, C. Effects of realistically simulated, elevated UV irradiation on photosynthesis and pigment composition of the alpine snow alga Chlamydomonas nivalis and the arctic soil alga Tetracystis sp. (Chlorophyceae). Photosynthetica 2010, 48, 269-277. [CrossRef]

275. Steiger, S.; Sandmann, G. Cloning of two carotenoid ketolase genes from Nostoc punctiforme for the heterologous production of canthaxanthin and astaxanthin. Biotechnol. Lett. 2004, 26, 813-817. [CrossRef]

276. Koller, M.; Muhr, A.; Braunegg, G. Microalgae as versatile cellular factories for valued products. Algal Res. 2014, 6, 52-63. [CrossRef]

277. Pleissner, D.; Lindner, A.V.; Händel, N. Heterotrophic cultivation of Galdieria sulphuraria under non-sterile conditions in digestate and hydrolyzed straw. Bioresour. Technol. 2021, 337, 125477. [CrossRef] [PubMed]

278. Massa, M.; Buono, S.; Langellotti, A.L.; Martello, A.; Russo, G.L.; Troise, D.A.; Sacchi, R.; Vitaglione, P.; Fogliano, V. Biochemical composition and in vitro digestibility of Galdieria sulphuraria grown on spent cherry-brine liquid. New Biotechnol. 2019, 53, 9-15. [CrossRef] [PubMed]

279. Singh, P.; Rani, B.; Chauhan, A.K.; Maheshwari, R. Lycopene's antioxidant activity in cosmetics meadow. Int. Res. J. Pharm. 2013, 3, 46-47.

280. Hashtroudi, M.S.; Shariatmadari, Z.; Riahi, H.; Ghassempour, A. Analysis of Anabaena vaginicola and Nostoc calcicola from Northern Iran, as rich sources of major carotenoids. Food Chem. 2013, 136, 1148-1153. [CrossRef]

281. Keen, M.A.; Hassan, I. Vitamin E in dermatology. Indian Dermatol. Online J. 2016, 7, 311-315. [CrossRef]

282. Carrero, A.; Vicente, G.; Rodríguez, R.; Linares, M.; del Peso, G.L. Hierarchical zeolites as catalysts for biodiesel production from Nannochloropsis microalga oil. Catal. Today 2011, 167, 148-153. [CrossRef]

283. Shelest, E.; Heimerl, N.; Fichtner, M.; Sasso, S. Multimodular type I polyketide synthases in algae evolve by module duplications and displacement of AT domains in trans. BMC Genomics 2015, 16, 1015. [CrossRef]

284. Sasso, S.; Pohnert, G.; Lohr, M.; Mittag, M.; Hertweck, C. Microalgae in the post-genomic era: A blooming reservoir for new natural products. FEMS Microbiol. Rev. 2013, 36, 761-785. [CrossRef]

285. John, U.; Beszteri, B.; Derelle, E.; Van de Peer, Y.; Read, B.; Moreau, H.; Cembella, A. Novel insights into evolution of protistan polyketide synthases through phylogenomic analysis. Protist 2008, 159, 21-30. [CrossRef]

286. Fan, Q.; Huang, G.; Lechno-Yossef, S.; Wolk, C.P.; Kaneko, T.; Tabata, S. Clustered genes required for synthesis and deposition of envelope glycolipids in Anabaena sp. strain PCC 7120. Mol. Microbiol. 2005, 58, 227-243. [CrossRef]

287. Shulse, C.N.; Allen, E.E. Widespread occurrence of secondary lipid biosynthesis potential in microbial lineages. PLoS ONE 2011, 6, e20146. [CrossRef] [PubMed]

288. Stewart, J.S.; Lignell, A.; Pettersson, A.; Elfving, E.; Soni, M.G. Safety assessment of astaxanthin rich microalgae biomass: Acute and subchronic toxicity studies in rats. Food Chem. Toxicol. 2008, 46, 3030-3036. [CrossRef] [PubMed]

289. Spiller, G.A.; Dewell, A. Safety of an astaxanthin rich Haematooccus pluvialis algal extract: A randomized clinical trial. J. Med. Food 2003, 6, 51-56. [CrossRef]

290. Hofbauer, W.K. Toxic or otherwise harmful algae and the built environment. Toxins 2021, 13, 465. [CrossRef] [PubMed]

291. Thiyagarasaiyar, K.; Goh, B.H.; Jeon, Y.J.; Yow, Y.Y. Algae Metabolites in Cosmeceutical: An Overview of Current Applications and Challenges. Mar Drugs 2020, 18, 323. [CrossRef] [PubMed] 